\title{
Flax Fiber for Technical textile: a life cycle inventory
}

Alejandra Gomez-Campos ${ }^{1 *}$, Claire Vialle ${ }^{1 *}$, Antoine Rouilly ${ }^{1}$, Caroline Sablayrolles ${ }^{1}$, Lorie Hamelin ${ }^{2}$

${ }^{1}$ Laboratoire de Chimie Agro-industrielle, LCA, Université de Toulouse, INRAE, Toulouse, France

${ }^{2}$ Toulouse Biotechnology Institute (TBI), INSA, INRAE UMR792 and CNRS UMR5504, Federal University of

Toulouse, 135 Avenue de Rangueil, F-31077, Toulouse, France

*Corresponding authors (alejandra.gomezcampos@ensiacet.fr / claire.vialle@ensiacet.fr)

This is a non-peer review preprint submitted to Preprints.org. This manuscript has been submitted for publication in the Journal of Cleaner Production. Please note that, despite having undergone peerreview, the manuscript has yet to be formally accepted for publication. Subsequent versions of this manuscript may have slightly different content. 


\title{
Flax Fiber for Technical textile: a life cycle inventory
}

\author{
Alejandra Gomez-Campos ${ }^{1 *}$, Claire Vialle ${ }^{1 *}$, Antoine Rouilly $^{1}$, Caroline Sablayrolles $^{1}$, Lorie Hamelin ${ }^{2}$ \\ ${ }^{1}$ Laboratoire de Chimie Agro-industrielle, LCA, Université de Toulouse, INRAE, Toulouse, France \\ ${ }^{2}$ Toulouse Biotechnology Institute (TBI), INSA, INRAE UMR792 and CNRS UMR5504, Federal University of \\ Toulouse, 135 Avenue de Rangueil, F-31077, Toulouse, France \\ *Corresponding authors (alejandra.gomezcampos@ensiacet.fr / claire.vialle@ensiacet.fr)
}

\section{KEYWORDS}

Consequential LCA; System expansion; Life Cycle Assessment; flax fiber biobased materials; bioeconomy

\section{ABSTRACT}

Flax fiber appears as a suitable feedstock in the endeavor of deploying a sustainable biobased economy. Its environmental performance as reinforcement in composite materials has been studied in previous Life Cycle Assessments (LCAs). However, these studies only present a coarse Life cycle Inventory (LCI) and often fail to detail all processes of the supply chain or to represent the co-products. This paper aims to bridge this gap and provide data for future LCAs on flax fiber production and transformation.

The study focuses on the impacts of producing a bio-based reinforcement material (a fabric product for nonaesthetic purposes) with a system expansion perspective. The functional unit is defined as the production of $2400 \mathrm{~m}^{2}$ flax-based technical textile per year, this corresponds to one hectare of cultivated land. The geographical scope considers that the production occurs in France and that some manufacturing process are outsourced in China. A Sensitivity Analysis was carried out to assess the influence of the electricity mix in the various countries involved in the manufacturing cycle.

A detailed life cycle inventory for flax fiber production and transformation was built and the environmental performance of a flax technical textile was assessed as a cradle-to-gate LCA. The fate of co-products was documented and was shown to contribute to the reduction of the generated environmental impacts.

Through a cradle-to-gate LCA, a broader understanding of the environmental performance of a flax-based technical textile was presented by including the valorization of co-products and a wider set of analyzed impact categories, going therefore beyond the existing state-of-the-art. Results show agricultural activities and electricity production to be the biggest contributors to the environmental impacts of flax technical textile; contributions due to land use changes were minor in comparison. Very specifically for this case study, a sensibility analysis showed the influence of an all-French production to be more efficient from an environmental point of view.

\section{INTRODUCTION}

The latest update of the European Commission's (EC) Bioeconomy Strategy (EC 2018) sheds light on the strategic role of bio-based products and services in the transition towards a post-fossil carbon economy, bringing both innovative and sustainable solutions to global challenges such as climate change, land- and ecosystem degradation. Because it allows decoupling the material and in particular, the chemical sector from the use of 
fossil carbon, bio-based materials is a growing and encouraged market throughout Europe (EC 2018). In France, for example, the national Bioeconomy Action Plan suggests to use bio-based materials for the construction of the Olympic Village 2024, among others (Ministère de l'Agriculture et de l'Alimentation 2018).

Flax (Linum usitatissimum) has been long used as a source of textile fibers. Lately, it has also been used to meet technical applications such as reinforcement for composite materials. In fact, natural-fiber reinforced materials are increasingly being used as a substitute for glass fiber reinforced composites, particularly in the automotive sector (Deng and Tian 2015; Yan et al. 2014), since it allows a weight reduction of parts of ca. 5\% (Le Duigou and Baley 2014), among other benefits. Amongst the different natural fibers being used, flax represented $50 \%$ of the market share for composites in 2012 (Barth and Carus 2015).

Worldwide, Europe accounts for $70 \%$ of the world's flax production, with the French Normandy region responsible for ca. 85\% of the European production (C.E.L.C. 2010a; FAOSTAT 2017), making France the world leader of flax fiber production. This reflects the suitable agronomic conditions provided in the North of France (humid climate and nutrient rich soils) for the cultivation of flax, combined with a long-established know-how for cultivating and supplying this crop for the flax seed and fiber market. At the European level, there are about 140 flax fiber-processing plants and France has the installed capacity to carry out all stages of the supply chain (C.E.L.C. 2010a) i.e. the cultivation stage up to the final weaving into technical or textile fabric.

C.E.L.C. (2010) states that the cultivation of one hectare of flax fiber contributes to stock 3.7 tonnes of $\mathrm{CO}_{2}$ (below-ground carbon). Moreover, most co-products generated through the flax fiber transformation stages are re-circulated into the economy and valorized as new products (C.E.L.C. 2010b). The environmental performance of flax fiber reinforced composites has been assessed in previous Life Cycle Assessment (LCA) studies (Bachmann et al. 2017; Le Duigou et al. 2011; van der Werf and Turunen 2008; Bensadoun et al. 2016). However, these studies do not focus on the production of the flax fiber technical textile per se and, therefore, lack detailed information on the LCl. Additionally, co-products are handled by using economic allocation techniques and their fate is little discussed or specified.

Flax thus appears as a potentially important feedstock to a Europe aiming to deploy a sustainable bioeconomy. However, the full consequences induced by the use of flax as a source of fiber to replace glass fibers has been little studied.

To the authors' knowledge, current work on LCAs assessing the environmental impact of flax fibers as reinforcement on composite materials is limited and what is available either does not address the whole supply chain of flax fiber transformation (from cultivation to weaving into a technical textile) or lacks transparent information on the LCl used. Le Duigou et al. (2011) presented LCl data up until the combing process and used mass allocation to artificially attribute parts of the impacts to the studied product only. On the other hand, Deng and Tian (2015) did follow a consequential approach, but accounted only for seeds, short fibers, shives and flax tow as co-products; whereas in this work every co-product emerging in the supply chain were accounted for, along with consequences of demanding constrained resources (e.g. land use changes). 
In an endeavor to bridge this gap, the purpose of this study is to assess the environmental performance associated to transforming flax fibers into a technical fabric used as reinforcement in a composite material, in the short-term horizon. It also aims to provide transparent, clear and precise inventory data for future LCAs to be carried out for flax fiber intended for the technical textile sector.

\section{MATERIAL AND METHODS}

\subsection{LCA approach}

The Life Cycle Assessment was carried out with the SimaPro LCA software, version 8.5.2. The impact assessment method ILCD 2001 Midpoint+ was used but slightly adapted based on the recommendations from the European Commission (EC) "product environmental footprint category rules" (PEFCR; EC 2017), themselves based upon the IPCC update published in their Fifth Assessment Report (AR5; IPCC 2013). This affects the GWP 100 of i) biogenic methane (34 kg CO $2 \mathrm{eq}$ ); ii) non-biogenic methane (36.75 kg CO 2 eq) and iii) carbon monoxide, fossil and from land use changes ( $1.57 \mathrm{~kg} \mathrm{CO} 2 \mathrm{eq})$.

From the 16 impact categories proposed by ILCD 2001 Midpoint+, the following were selected to be part of the assessment, being explicitly mentioned in the European Commission policy recommendation (EC 2013) for the methods to use for LCA, namely: Climate change, Ozone depletion, Particulate matter, Photochemical ozone formation, Acidification, Freshwater eutrophication, Marine eutrophication and Mineral, fossil \& renewable resource depletion. Moreover, to include impacts related to the use of nuclear energy, the impact category lonizing radiation (Human Health) was included as well.

Although no official guidelines exist about this specific issue, LCAs are often labeled as "attributional" or "consequential" (e.g. (Ekvall et al. 2016; Finnveden et al. 2009; Hamelin 2013; Weidema et al. 2018)), though other (e.g. advanced attributional) or additional (e.g. prospective, hybrid, etc.), labels are also used. The LCA performed herein could be referred as "consequential" (Brandão et al. 2017; Earles and Halog 2011), i.e. no coproducts are left out from the system boundaries and all their exchanges from and to the environment, in terms of material and substance flows, are fully taken into account. This approach allows to gain insights of the environmental burdens associated to changes in demand and ultimately to foresee the environmental consequences of a decision being made (Sonnemann and Vigon 2011).

Accordingly, a system expansion approach was taken, and allocation techniques were avoided, as recommended in ISO 14040 and 14044 (ISO 14040 2006; ISO 14044 2006). Background data were extracted from two life cycle inventory databases, namely Ecoinvent v3.4 and Agribalyse v1.3 (a French specific agricultural database) from which "consequential processes" (Weidema et al. 2013; Wernet et al. 2016) or identified marginal processes were selected.

2.2. Goal

This study focuses on the impacts of producing a bio-based reinforcement material; from this point onwards, to be referred to as "technical textile", i.e. a fabric product manufactured for non-aesthetic purposes. In subsequent steps, this technical fabric is impregnated with a thermoplastic or thermosetting all-polymeric matrix (e.g. epoxy, 
polyester, vinyl-ester resins, among others) to form a composite material. It is the long-term vision of the authors to address the consequences of the use of such bio-based technical textile for the aviation sector, though this full assessment is beyond the scope of the present study. The present study follows therefore a cradle-to-gate approach; it encompasses all steps of flax fiber production and transformation, from the fields up until (and including) the production stage, i.e. just prior to blend the fabric with the polymeric resin. The work carried out aims to provide a complete $\mathrm{LCl}$ for future LCA studies to be performed.

\subsection{Functional Unit}

The functional unit is defined as the production of $2330 \mathrm{~m}^{2}$ flax-based technical textile per year, having the required properties for an eventual use in the aviation sector. This corresponds to one hectare of cultivated land, from which about $7000 \mathrm{~kg}$ of flax green stems (wet weight; ww) are harvested per year (mean yield value of the last ten years according to data from FAOSTAT, 2017). For tractability reasons, the results will be here expressed per ha of land used for the cultivation of flax.

\subsection{Scope}

Geographical scope. The geographical scope considers that the production stems from a company located in France; parts of the manufacturing process are however outsourced in China. In other words, the cultivation and initial stages of the flax fibers conversion takes place in France (the inventory data reflects the French bio-physical and legislative conditions), while the last steps of the process chain take place in China (under the applying Chinese context for the use of electricity and other inputs). Background systems affected outside these two countries (e.g. the production of fertilizers) are also included, in accordance with state-of-the-art LCA principles (ISO 14040 2006; ISO 14044 2006).

According to C.E.L.C (2010) the European flax fiber production market is represented by over 10000 companies distributed in 14 European countries. Europe is responsible for $80 \%$ of the world's flax fibers (scutched fibers) production and over $60 \%$ of the registered suppliers of technical fabric are located in France. However, China is considered the world leader of textile-clothing production (IFM 2004) as it makes up for 22 and $24 \%$ of the world's installed capacities for spinning and weaving, respectively (BIOIntelligence Service 2007). Hence, these last steps of the production are considered to take place in China.

Temporal Scope. The temporal scope of the study considers the short-term horizon, i.e. data from "current" production practices were collected, assuming they can be representative of future production conditions. In other words, our data represent "today's" production and are judged valid to represent the production taking place within the next five to ten years.

\section{LIFE CYCLE INVENTORY (LCI)}

3.1. Overview 
The identified supply chain stages to obtain a flax fibers technical fabric are presented in Figure 1 along with the various co-products emerging from these, and their fate.

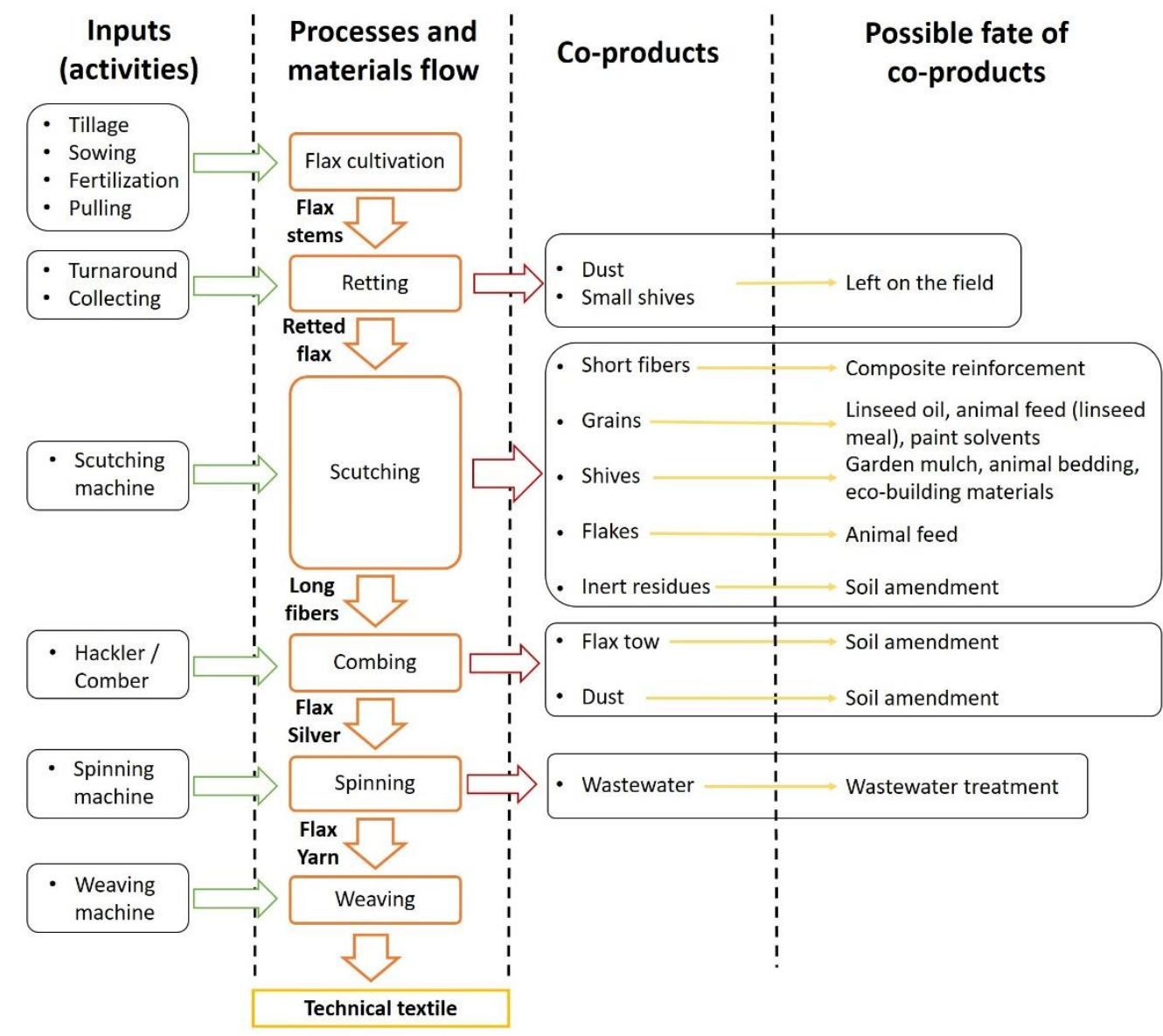

Figure 1. Process tree including input and output flows and the fate of co-products

The overall input and output flows to and from the system's boundaries in terms of materials and emissions are summarized in Table 1 (foreground data). These are represented per ha of cultivated land; values above one hectare in Table 1 mean that more than one passage of the agricultural machinery is required. For plowing, for example, machinery passes three times, each time covering the totality of the one-hectare field. This is the same for the application of fertilizers and plant protection products. As it can be seen from Table 1, the foreground inventory data considered for the flax cultivation, scutching, combing, spinning and weaving processes were essentially drawn from the work of Bensadoun et al. (2016), BIOIntelligence Service (2007) and Le Duigou et al. (2011); the only existing inventories documenting French flax production. The work behind these inventories was based on data from the industry, albeit indirectly (namely from the "Institute Technique du Lin", a French organization that manages the production and transformation of flax fiber) and the C.E.L.C.

The life cycle inventory for the retting stage as well as for the use of the co-products have not been documented before and are a novelty of this study. The hypothesis, calculations and data source behind these inventories are detailed in the Supporting Information (SI) Word document. All background processes (e.g. agricultural activities, production of fertilizers) involved were retrieved from the Ecoinvent v 3.4 database; the exact processes used are documented in the SI Excel document. 
Table 1. Values of input and output flows from the technical textile supply chain. All units are per hectare of cultivated land per year.

\begin{tabular}{|c|c|c|c|c|c|c|c|}
\hline \multicolumn{4}{|c|}{ FLAX CULTIVATION } & \multicolumn{4}{|c|}{ RETTING } \\
\hline \multicolumn{2}{|l|}{ Input } & Value & Units & \multicolumn{2}{|l|}{\begin{tabular}{|l|} 
Input \\
Flax stems
\end{tabular}} & Value & Units \\
\hline \multirow{3}{*}{ Tillage } & Plowing & 3 & ha & \multicolumn{2}{|l|}{ Flax stems } & 7000 & $\mathrm{~kg}$ \\
\hline & Rotary cultivator & 1 & ha & \multicolumn{2}{|l|}{ Land Use } & 1 & ha \\
\hline & Harrowing & 1 & ha & \multirow{2}{*}{ Agricultural Machinery } & Turnover & 2 & ha \\
\hline Sowing & & 1 & ha & & Collecting & 4.67 & $\mathrm{~m}^{3}$ \\
\hline Fertilizing \& zinc ap & cation by broadcaster & 3 & ha & Output* & & & \\
\hline Plant protection $(\mathrm{He}$ & icides\&Pesticides) by field sprayer & 5.5 & ha & Retted flax & & 6230 & $\mathrm{~kg}$ \\
\hline Pulling & & 1 & ha & $\mathrm{CO}_{2}$ emissions & & 545 & $\mathrm{~kg}$ \\
\hline Seeds & & 115 & $\mathrm{~kg}$ & $\mathrm{CH}_{4}$ emissions & & 4.55 & $\mathrm{~kg}$ \\
\hline Land Use & & 1 & ha*a & CO emissions & & 1.21 & $\mathrm{~kg}$ \\
\hline & Potassium chloride & 117 & $\mathrm{~kg}$ & $\mathrm{NH}_{3}$ emissions & & 0.42 & $\mathrm{~kg}$ \\
\hline Fertilizers & Ammonium nitrate phosphate & 86 & $\mathrm{~kg}$ & $\mathrm{~N}_{2} \mathrm{O}$ direct emissions & & 0.098 & $\mathrm{~kg}$ \\
\hline & Triple superphosphate & 146 & $\mathrm{~kg}$ & $\mathrm{~N}_{2} \mathrm{O}$ indirect emissions & & $5.4 \mathrm{E}-05$ & $\mathrm{~kg}$ \\
\hline & Carbendazime / Benzimidazole & 150 & $\mathrm{~g}$ & & SCUTCHING & & \\
\hline Pesticides & Prochloraze & 38 & $\mathrm{~g}$ & Input & & & \\
\hline 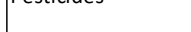 & Flusilazole & 300 & $\mathrm{~g}$ & Retted flax & & 6230 & $\mathrm{~kg}$ \\
\hline & Thirame & 73 & $\mathrm{~g}$ & \begin{tabular}{|l|} 
Electricity \\
\end{tabular} & & 723 & $\mathrm{kWh}$ \\
\hline & Triallate & 144 & $\mathrm{~g}$ & \begin{tabular}{|l} 
Transport from field \\
\end{tabular} & & 249 & $\mathrm{tkm}$ \\
\hline Herbicides & Linuron & 90 & $\mathrm{~g}$ & Output & & & \\
\hline & Bentazone & 1584 & $\mathrm{~g}$ & Long fibers & & 1470 & $\mathrm{~kg}$ \\
\hline Insecticides & Deltamethrin / Pyrethroid & 15 & $\mathrm{~g}$ & Short fibres & & 770 & $\mathrm{~kg}$ \\
\hline & For seed's treatment & 414 & $\mathrm{~g}$ & Grains & & 350 & $\mathrm{~kg}$ \\
\hline Liाi & For soil treatment after sowing & 1000 & $\mathrm{~g}$ & Shives & & 2520 & $\mathrm{~kg}$ \\
\hline Copper & & 9.53 & $\mathrm{~g}$ & Flakes & & 490 & $\mathrm{~kg}$ \\
\hline Iron & & 3.48 & $\mathrm{~kg}$ & Inert residues & & 630 & $\mathrm{~kg}$ \\
\hline Calcium & & 30.24 & $\mathrm{~kg}$ & Co-products fate* & & & \\
\hline Carbon dioxide (cap & red from air) & 10395 & $\mathrm{~kg}$ & Production of glass fibre cc & osites (Short fibres) & -693 & $\mathrm{~kg} \mathrm{DM}$ \\
\hline Output & & & & Marginal oil production (Li & ed oil from Grains) & -99 & $\mathrm{~kg}$ \\
\hline Flax stems & & 7000 & $\mathrm{~kg}$ & & Marginal protein (soybean) & -177 & $\mathrm{~kg} \mathrm{FM}$ \\
\hline Induced Land Use $\mathrm{Cl}$ & & 0.05 & ha & production (Linseed meal) & Marginal carbohydrate (maize) & -149 & $\mathrm{~kg}$ \\
\hline & Ammonia & 0.73 & $\mathrm{~kg}$ & & Marginal fats (palm oil) & -3.83 & $\mathrm{~kg}$ \\
\hline & Dinitrogen monoxide & 0.49 & $\mathrm{~kg}$ & Avoided Land Use Change & & -0.013 & ha \\
\hline & Nitrogen dioxide & 0.1 & $\mathrm{~kg}$ & Combustion of woody resi & & 41 & MJ \\
\hline Emissions to air & Carbendazim & 7.5 & $\mathrm{~g}$ & Heat production from natu & jas (Shives) & -33 & GJ \\
\hline 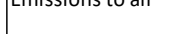 & Triallate & 136.8 & $\mathrm{~g}$ & Marginal animal feed & Marginal protein (soybean) & -81 & $\mathrm{~kg}$ \\
\hline & Linuron & 45 & $\mathrm{~g}$ & production (Flakes) & Marginal fibre (hay) & -666 & $\mathrm{~kg}$ \\
\hline & Bentazone & 237.6 & $\mathrm{~g}$ & Use of inert residues as am & Iment & 630 & $\mathrm{~kg}$ \\
\hline & Deltamethrin (pyrethroid) & 0.15 & $\mathrm{~g}$ & & COMBING & & \\
\hline & Carbendazim & 0.75 & $\mathrm{~g}$ & Input & & & \\
\hline & Triallate (groundwater) & 1.57 & $\mathrm{~g}$ & Long fibers & & 1470 & $\mathrm{~kg}$ \\
\hline & Triallate (river) & 0.86 & $\mathrm{~g}$ & Electricity & & 809 & $\mathrm{kWh}$ \\
\hline & Linuron & 0.45 & $\mathrm{~g}$ & Output & & & \\
\hline & Bentazone & 7.9 & $\mathrm{~g}$ & Flax Sliver & & 980 & $\mathrm{~kg}$ \\
\hline & Deltamethrin (pyrethroid) & 0.075 & $\mathrm{~g}$ & Flax tow & & 420 & $\mathrm{~kg}$ \\
\hline & Nitrate & 25 & $\mathrm{~kg}$ & Dust & & 70 & $\mathrm{~kg}$ \\
\hline & Phosphate & 0.93 & $\mathrm{~kg}$ & Co-products fate* & & & \\
\hline & Nickel (river) & 1.51 & $\mathrm{~g}$ & Use of inert residues as am & Iment & 490 & $\mathrm{~kg}$ \\
\hline & Phosphorus (groundwater) & 0.07 & $\mathrm{~kg}$ & & SPINNING & & \\
\hline & Phosphorus (river) & 0.276 & $\mathrm{~kg}$ & Input & & & \\
\hline Emissions to water & Cadmium (groundwater) & 42.24 & $\mathrm{mg}$ & Flax Sliver & & 980 & $\mathrm{~kg}$ \\
\hline & Cadmium (river) & 18.68 & $\mathrm{mg}$ & Electricity & & 4414 & $\mathrm{KWh}$ \\
\hline & Chromium (groundwater) & 20.87 & $\mathrm{~g}$ & Gas & & 24024 & MJ \\
\hline & Chromium (river) & 2.18 & $\mathrm{~g}$ & Water & & 12.74 & $\mathrm{~m}^{3}$ \\
\hline & Lead (groundwater) & 102.7 & $\mathrm{mg}$ & Lubricating oil & & 49 & $\mathrm{~kg}$ \\
\hline & Lead (river) & 307.3 & $\mathrm{mg}$ & Transport from Combing fa & $y$ to port & 147 & $\mathrm{tkm}$ \\
\hline & Mercury (groundwater) & 0.17 & $\mathrm{mg}$ & Transport from port to port & & 19110 & $\mathrm{tkm}$ \\
\hline & Mercury (river) & 0.44 & $\mathrm{mg}$ & Transport from port to fact & & 196 & $\mathrm{tkm}$ \\
\hline & Zinc (groundwater) & 10.4 & $\mathrm{~g}$ & Output & & & \\
\hline & Zinc (river) & 1.44 & $\mathrm{~g}$ & Flax Yarn & & 910 & $\mathrm{~kg}$ \\
\hline & Copper (groundwater) & 2.73 & $\mathrm{~g}$ & Wastewater & & 12.74 & $\mathrm{~m}^{3}$ \\
\hline & Copper (river) & 1.4 & $\mathrm{~g}$ & & WEAVING & & \\
\hline & Arsenic (As) & 0.56 & $\mathrm{~g}$ & Input & & & \\
\hline & Cadmium (Cd) & 18 & $\mathrm{~g}$ & Flax Yarn & & 910 & $\mathrm{~kg}$ \\
\hline & Cobalt (Co) & 1.5 & $\mathrm{~g}$ & Electricity & & 11830 & kWh \\
\hline & Chromium (Cr) & 92 & $\mathrm{~g}$ & Starch & & 159 & $\mathrm{~kg}$ \\
\hline & Copper (Cu) & 17 & $\mathrm{~g}$ & Transport from factory to $p$ & & 168 & $\mathrm{tkm}$ \\
\hline Emissions to soil & Iron (Fe) & 5965 & $\mathrm{~g}$ & Transport from port to port & & 16380 & $\mathrm{tkm}$ \\
\hline Linssions tosom & Mercury (Hg) & 0.011 & $\mathrm{~g}$ & Transport from port to dist & tion place & 168 & $\mathrm{tkm}$ \\
\hline & Molybdenum (Mo) & 1.2 & $\mathrm{~g}$ & Output & & & \\
\hline & Nickel (Ni) & 17 & $\mathrm{~g}$ & Technical textile & & 840 & $\mathrm{~kg}$ \\
\hline & Lead $(\mathrm{Pb})$ & 2.2 & $\mathrm{~g}$ & & & & \\
\hline & Selenium (Se) & 1 & $\mathrm{~g}$ & & & & \\
\hline & $\operatorname{Zinc}(\mathrm{Zn})$ & 116 & $\mathrm{~g}$ & & & & \\
\hline
\end{tabular}

*Calculated data (specified in their respective sections and in the SI). 


\subsection{System boundaries}

As previously discussed, system expansion was used to quantify the environmental impacts stemming from the co-products. Their inclusion into the system boundaries was done by identifying their most common use in the market, along with identifying the marginal (avoided) processes that would most likely be reacting to the demand change induced by their introduction to the market (Figure 2). These choices were validated by experts and professionals of the sector.

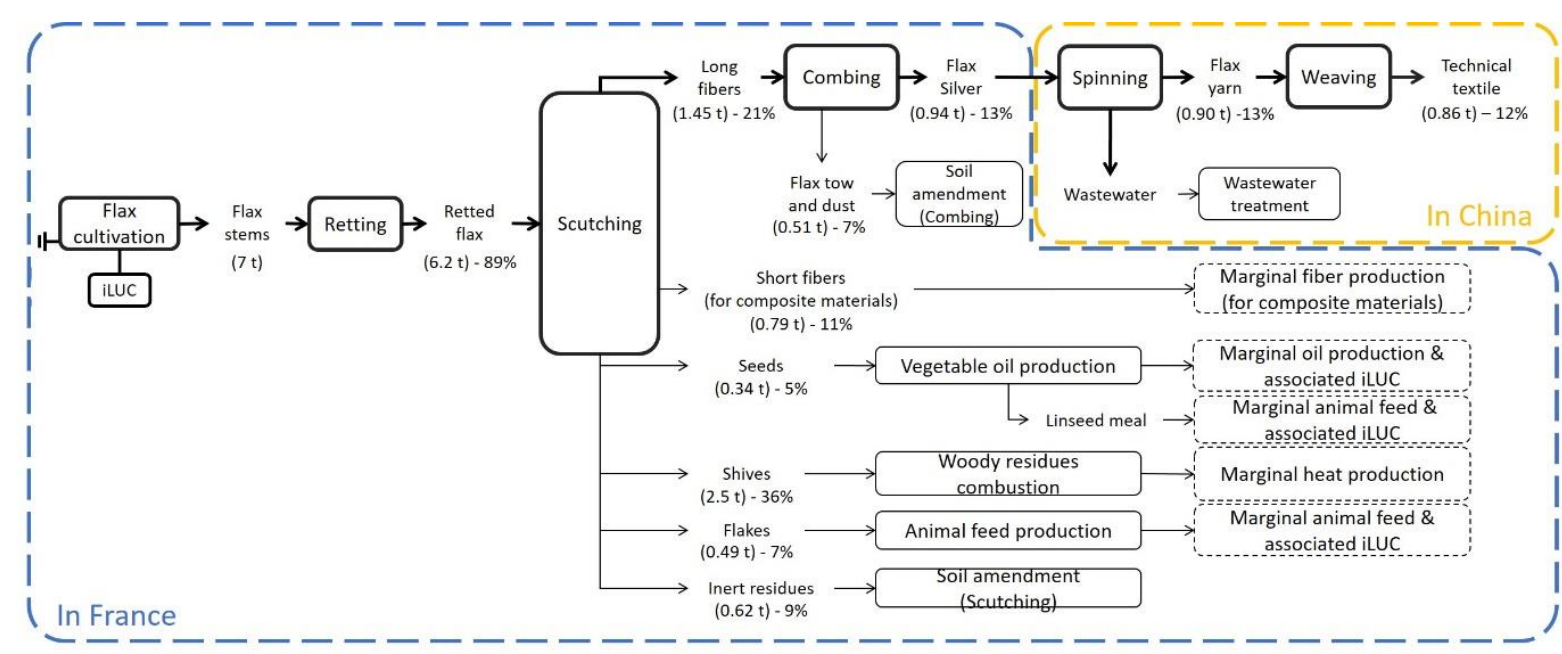

Figure 2. Process flow diagram illustrating the fate of the co-products from the production of a flax fiber technical textile. Boxes represent induced processes while dotted lines represent avoided processes

Other than agricultural machinery, infrastructure of foreground data is not taken into consideration. On the other hand, infrastructure related to background data is included in the already existing Ecoinvent processes.

Transportation requirements and corresponding transport distances are documented in the Biolntelligence Service report (2007) and these were considered herein. A $40 \mathrm{~km}$ distance between the cultivation location and the scutching/combing facilities is considered to be covered by a $32 \mathrm{t}$ truck. The same transport goes for the distance between the scutching facility and the French port $(150 \mathrm{~km})$ from which flax fibers will be shipped by a transoceanic freight ship to the Nanjing port in China (19500 km). Fibers are then transported by land to a facility at $200 \mathrm{~km}$ where they will be spun and woven. The technical textile is afterwards sent back to France considering the same transportation route, except that once in France, a $200 \mathrm{~km}$ distance from the port to a selling point is covered by truck. In the model, transport processes are taken into consideration as part of the spinning and weaving processes; their influence is addressed in the discussion section.

\subsection{Flax cultivation}

For the cultivation of one hectare of flax fiber, about $115 \mathrm{~kg}$ of flax seeds are sowed. Sowing takes place between the months of March and April. After 100 days (blooming stage), the stems reach a height of one meter. As a result, by the month of July, $7000 \mathrm{~kg} \mathrm{ha}^{-1}$ of flax stems (ww) are harvested by pulling (not reaping). This is done particularly for flax grown to be used as a fiber source for textile production; by pulling the whole stem, along with the roots, farmers ensure that fibers will be as long as possible. 
Data for the planting and harvesting stages were collected from Biolntelligence Service (2007) and Le Duigou et al. (2011), as documented in the SI.

The impact of displacing land as additional arable land is demanded for flax cultivation, i.e. the so-called land use changes, was taken into account based on the approach described in a recently release study from the European Commission (EC 2019), itself updating the deterministic approach presented in Tonini et al. (2016). In a nutshell, this approach is based on an analysis of the global deforestation that occurred between $2000-2010$, and considers two key reactions to an increased demand for arable land, namely arable land expansion (85\% of the response) and agricultural intensification (15\% of the response; here translated as an additional fertilizer demand only). All carbon (carbon dioxide; $\mathrm{CO}_{2}$, methane; $\mathrm{CH}_{4}$ and carbon monoxide; $\mathrm{CO}$ ), nitrogen (ammonia; $\mathrm{NH}_{3}$, dinitrogen monoxide; $\mathrm{N}_{2} \mathrm{O}$, nitrogen oxides; $\mathrm{NO}_{x}$ and nitrates; $\mathrm{NO}_{3}{ }^{-}$) and phosphorus flows occurring as a result of these two responses were taken into account. When translated into $\mathrm{CO}_{2}$ eq, it results in an emission factor of $4.0 \mathrm{t} \mathrm{CO}_{2}$ eq ha ${ }^{-1} \mathrm{y}^{-1}$. Which is in the same order of magnitude as the factor derived by Tonini et al. (2016) (4.1 $\mathrm{t} \mathrm{CO}_{2}$ eq ha-1 $\mathrm{y}^{-1}$ ), but slightly above the factors derived by Schmidt and Muños (2014) (1.7 t $\mathrm{CO}_{2}$ eq ha-1 $\left.\mathrm{y}^{-1}\right)$; value for "world average arable land").

The iLUC value is obtained by considering the annualization of the use of 1 ha of land over 20 years, based on EU methods.

Removals of calcium, copper and iron from the ground were accounted for. The starting point for this was the composition of the flax plant (Heuzé et al. 2015). Here, it was considered that no external application of these micro-nutrients take place; therefore the whole quantities of these in the flax plant is assumed to stem from soil withdrawals. Biogenic $\mathrm{CO}_{2}$ captured by the plant was calculated through Equation 1 (Boutin et al. 2005). In this equation, $Q_{\mathrm{CO} 2}$ represents the amount of $\mathrm{CO}_{2}$ required by the plant to make up its weight in dry matter ( $\left.\mathrm{QDM}_{\mathrm{DM}}\right) ; \% \mathrm{C}$ corresponds to the carbon content of flax fibers (here 45\%; (Sharma and van Sumere 1992)) and Mco2 and Mc represent the molar mass of $\mathrm{CO}_{2}$ and $\mathrm{C}$, respectively.

Equation $1-Q_{\mathrm{CO}_{2}}=\left(Q_{D M} * \%_{C}\right) *\left(\frac{M_{C O_{2}}}{M_{C}}\right)$

Flax's nitrogen requirements are low and sensitive to the quality of the soil. According to ADEME and ITCF (1998), an input of 10-20 kg ha-1 suffices for a high quality soil, while $40 \mathrm{~kg} \mathrm{ha}^{-1}$ are needed for soils with less humus content. Independently of the soil quality, potassium $\left(\mathrm{K}_{2} \mathrm{O}\right)$ and phosphate $\left(\mathrm{P}_{2} \mathrm{O}_{5}\right)$ requirements amount each to $70 \mathrm{~kg} \mathrm{ha}^{-1}$. For this study an average of $30 \mathrm{~kg} \mathrm{ha}^{-1}$ was considered as nitrogen input. The specific fertilizers considered are based on the Biolntelligence Report (2007) and correspond to the marginal fertilizers identified by Hamelin (2013) for Europe, namely: ammonium nitrate (35\% $\mathrm{N}$ content), potassium chloride $\left(60 \% \mathrm{~K}_{2} \mathrm{O}\right.$ content) and triple superphosphate (48\% $\mathrm{P}_{2} \mathrm{O}_{5}$ content). Similarly, the application of pesticides and herbicides was modelled based on the data from the Biolntelligence report (2007).

\subsection{Retting}

The first transformation step from plant to fiber is the retting process. Once the stems are pulled, they are laid over the field in windrows of approximately 1 meter long and left to "rot" by the enzymatic action of the 
microorganisms present in the soil, being exposed to rain and other climate conditions particular to the region. Stems must be well aligned and not too tight to avoid mold (GNIS 2018b). To optimize the retting process, farmers will turn over the stems to obtain a homogeneous result. The quality of the fibers depends greatly on how well the retting was carried out by the farmers.

During the process, the pectins that bind the fibers to the woody part of the plant are depolymerized. This step can take from two to 12 weeks depending on the climate conditions and the industrial requirements for the fiber. At the end of the retting process, when the flax stems are sufficiently dry (less than $15 \%$ moisture content) they are stored rolled up in round or rectangular bales.

As confirmed by experts from the French organization "Union Syndicale des Rouisseurs-Teilleurs de Lin" (USRTL), no biomass is left on the field after collection of the retted stems. Possible dust and small shives produced from the retting process and their contribution to adverse health or as an input of carbon and macronutrients to soil are considered as negligible. Therefore, the mass loss is assumed to be emissions to air.

Consequently, carbon $\left(\mathrm{CO}_{2}, \mathrm{CO}, \mathrm{CH}_{4}\right)$ and nitrogen $\left(\mathrm{N}_{2} \mathrm{O}, \mathrm{NO}_{\mathrm{x}}, \mathrm{NH}_{3}\right)$ emission flows from the decomposition of biomass were estimated in order to model the overall environmental impact of the retting process. Carbon losses were calculated considering that $22 \%$ of the total mass loss happens in the form of carbon. This proxy is based upon ongoing research (Bleuze 2019) on the retting of hemp under industrial condition as no quantified data characterizing the degradation of flax during the retting process was available. By considering an overall mass loss of $11 \%$ (Table 1; specifications in SI) and a dry matter content of 90\% for flax (Heuzé et al. 2015), the total carbon losses amount to about $150 \mathrm{~kg} \mathrm{Closs} \mathrm{ha}^{-1}$, being lost as of $\mathrm{CO}_{2}, \mathrm{CO}$ and $\mathrm{CH}_{4}$, as further detailed in the $\mathrm{SI}$. Regarding nitrogen emissions, it was considered that losses correspond to $0.06 \%$ of the dry matter (DM), based on Hamelin et al. (2014); which translates into $0.42 \mathrm{~kg} \mathrm{~N}$ loss ha $^{-1}$. These were considered to occur as $\mathrm{N}_{2} \mathrm{O}$ and $\mathrm{NH}_{3}$; details of the calculations can be found in the SI.

\subsection{Scutching}

Retted stems are baled and transferred to scutching facilities where the wood-like part of the stem is broken up for the fibers to be accessible. This is the first mechanical transformation of the fibers and a process in which numerous co-products are generated, namely long fibers that go from 60 to $90 \mathrm{~cm}$ (GNIS 2018a) (desired output), short fibers below $60 \mathrm{~cm}$, grains, shives, flakes and plant residues that may include some dust and soil (Figure 1). The energy input related to this process was modelled according to BIOIntelligence Service (2007) and Le Duigou et al. (2011), as well as the mass percentages of the different co-products resulting from this step.

Bales are unrolled on carpets and, after having recovered the seeds by beating them, flax stems are spread out parallel as they pass through a machine composed of a set of metal toothed rollers that crush, beat and then comb them to eliminate the inside wood-like core. Drum carders spinning at $200 \mathrm{rpm}$, where long and short fibers are separated, then clean the fibers. Long fibers are kept while the different co-products fall to the floor of the machine. Small components such as flakes and plant residues in the form of dust, are extracted by an aspiration system. 
Short fibers. As their name suggests, this co-product represent fibers of a reduced length. This co-product, also known as scutched tow, is essentially valorized as reinforcement in thermoplastic composite materials for leisure products (such as rackets, boards, skis, helmets, among others), automotive parts (e.g. dashboard, door panels), eco-building or composite furniture (C.E.L.C. Masters of Linen 2010). This application, i.e. reinforcement in composite materials, was therefore considered herein.

In some cases, short fibers undergo another cleaning process where high and low quality short fibers are distinguished. Low quality fibers are then used as insulation material for housing. Whether this additional step does take place or not is plant-dependent and was not considered in this life cycle assessment.

Here, the production of fiber-reinforced composites was considered to replace glass fiber reinforced composites in a 1 to 1 ratio. This assumption implies that markets are unconstrained, that supply is fully elastic (B. Weidema et al. 2013), and that both fibers deliver the same functionality per unit of mass. It was further considered that the type of fibers used (glass or flax) does not affect the quantity of resin needed to produce the composite material (resin was therefore left out of the system boundary). It was then considered that the $770 \mathrm{~kg}$ of short fibers produced per functional unit, avoid the production of $693 \mathrm{~kg}$ of glass fibers (considering a $90 \%$ DM content for the short fibers).

To represent the displaced glass fibers production (from the $770 \mathrm{~kg}$ of short fibers produced per functional unit), the process avoided glass fiber production was modelled, adapted from an existing process of the Ecoinvent v3.4 database, as further detailed in the SI Excel document.

Seeds. Linseeds are flat-shaped and have a bright, brown color. They are small and light, 2000 seeds weight around $10 \mathrm{~g}$; which corresponds to the dose required to sow one $\mathrm{m}^{2}$ of land (GNIS 2018a). They come inside a structure known as a capsule; each capsule is made up of two lobes that can contain 1-2 seeds. In total, 8-10 seeds can be obtained from one capsule.

Seeds are collected right at the beginning of the scutching process and are typically used to extract oil (Deng and Tian 2015), to be sold on the vegetable oil market, thereby replacing the production of marginal oil. This is here considered to be palm oil, as identified by Schmidt and Weidema (2007). In the linseed oil extraction process, linseed meal is generated as a co-product. Linseed meal is considered to be further valorized as animal feed. It has a higher protein quality than other commonly used sources of protein (Newkirk 2015) and there is no other real economic market for it (Chandrasekaran 2013). The LCA model considers that the carbohydrate, lipid and protein content of the meal replaces marginal carbohydrate, lipid and protein sources in animal feed, respectively. The marginal carbohydrate was taken to be maize, as identified by Tonini et al. (2016), the marginal protein to be soybean meal (Dalgaard et al. 2008), and the marginal lipid as palm oil (Schmidt and Weidema 2007).

Substitution factors were derived based on the nutritional valued of linseed meal and those of the marginal displaced feed ingredients (detailed in Table 1 and the SI), an approach similar to that taken by e.g. Tonini et al. (2016). The life cycle inventory of the displaced ingredients was retrieved from the Ecoinvent v3.4 database 
(consequential processes; exact processes documented in the SI). The so-called "oil loop" documented in Dalgaard et al. (2008), i.e. reflecting that the substituted palm oil is produced along with palm meal, whose displacement in turns affect other commodities, is taken into account through the use of these consequential processes of the Ecoinvent database.

Shives. Shives represent the inner core of the stem, a wood-like layer typically valorized as gardening mulch, animal litter and/or as eco-building materials in the form of chipboard panels (C.E.L.C. 2010a). For these three uses, an increased availability of shives involves a decrease in the use of wood residues. Wood waste (as wood chips for the case of gardening mulch and animal litter; and as a variety of streams for eco-building materials) is here considered as the marginal supplier for these uses. In other words, it is considered to be the least competitive supplier of these services, and thus the one to be displaced as a new alternative (here shives) becomes available. The fate considered for this increased availability of wood waste (no longer needed where shives are now used) is combustion in a $300 \mathrm{~kW}$ furnace with silo, supplying heat for district heating. This is based upon the findings of Projet AF Filières (2018), presenting a detailed material flow analysis of woody resources for the whole of France. The heat produced by these wood residues would then induce a decrease on the use of natural gas, the latter representing the marginal heat source for France.

The composition of flax shives and wood chips, in terms of DM, C and N, is very similar (C-51\% vs $50 \% ; \mathrm{N}-0.6 \%$ vs $0.4 \%$; expressed as \% of the DM and retrieved from the Phyllis database). This involves that the emissions and impacts linked to their respective management (prior to their use) can be expected to be very similar to one another; these were thus neglected herein.

In a nutshell, the overall management of shives implies two key processes, namely:

- Induced woody residues combustion, to represent the emissions from generating district heating heat from the displaced wood residues and,

- $\quad$ Avoided heat production from natural gas, which would have otherwise been used to generate that heat.

Detailed information on the processes used as proxys to model this can be found in the SI Excel document.

Flakes. Flakes represent the fibrous tissue covering the flax grains and can be further valorized as animal feed (BIOIntelligence Service 2007). The mechanical force applied to the fibers during the scutching process, causes the outer tissue of the grains to detach and fall. The nutritional content of flakes is high on fiber, but also contains protein (SI). Just like the calculations done for the valorization of linseed meal as animal feed, the fiber content of hay (marginal fiber) and soybean meal (marginal protein) were compared to the nutritional composition of flakes in order to derive the displacement ratios. The processes avoided soybean meal production (Flakes) and avoided hay production (Flakes) were created, as detailed in the SI.

Inert residues. Inert residues include the dust from the plant itself, small plant residues and soil carried out from the field with the flax stems. Based on personal communications with the stakeholders of the flax supply chain, these few centimeters of dusty residues are typically returned to nearby farmers and mixed with the 
amendments conventionally applied to soils. They are thus not used instead of fertilizers (or other amendments), but on top of these. Therefore, they do not replace marginal fertilizers. To model the emissions due to the application of this material on land (AoL), the algorithms detailed in Hamelin et al. (2014) for AoL were used, as further elaborated in Section 3 of the SI Word document.

\subsection{Combing}

Long fibers are combed for untangling and homogenization as well as removing small debris that may be left from the scutching process. Fibers are transformed into ribbons (flax sliver) and are ready to be spun into yarn. During this process, flax tow and plant residues are produced as inert materials. Similar to the inert residues produced during the scutching process, they are generally re-incorporated to nearby fields as amendment. The flows from and to the environment due to this were modelled using the same algorithms applied for the AoL of inert residues from the scutching process, as further detailed in the SI Excel document.

\subsection{Spinning}

Flax sliver is transported to China and spun into yarn by a process of untangling, regularizing, stretching and threating of the fibers. Wet spinning is a common practice to this end, and wastewater is generated as a result. This was represented in the model as Wastewater treatment (from spinning) as detailed in the SI.

\subsection{Weaving}

The last step is the weaving of the fabric. During this process, starch is usually used as a gluing agent. The result is a flax technical textile of $360 \mathrm{~g} / \mathrm{m}^{2}$. Detailed information on the input and exact processes used can be found in the SI Excel document.

\section{SENSITIVITY ANALYSIS (SA)}

The production process of flax-based technical textile takes place in different countries, namely France and China. Erreur ! Source du renvoi introuvable. highlights that China's marginal electricity mix mainly consists of coal (77\%) and hydropower (20\%), while France mainly relies on wind (84\%) and solar power (44\%) for their marginal electricity production (as modelled by the Ecoinvent v3.4 consequential processes for each country's electricity mix). Marginal sources of electricity represent the technologies that will be able to react to a surplus in demand.

Table 2. Marginal electricity mix for France and China (Source: Ecoinvent v3.4 processes)

\begin{tabular}{|l|c|c|}
\hline Electricity mix (2016) & France & China \\
\hline Coal & - & $77 \%$ \\
\hline Gas & - & $<1 \%$ \\
\hline Waste & $13 \%$ & - \\
\hline Nuclear & - & $2 \%$ \\
\hline Hydro & $<1 \%$ & $20 \%$ \\
\hline Solar PV & $44 \%$ & $<1 \%$ \\
\hline Wind & $84 \%$ & $<1 \%$ \\
\hline Geothermal & $2 \%$ & - \\
\hline
\end{tabular}


It has been shown several times (Ewertowska et al. 2016; Santoyo-Castelazo et al. 2011; Pehme et al. 2017) that electricity mixes involving less fossil supply (coal, natural gas, shale oil or gas) will yield an overall greater environmental performance, especially when it comes to climate change. To quantify the importance of the electricity mix for the present flax-based technical textile case, a virtual sensitivity analysis was made considering that all uses of electricity stems from the French electricity mix. This sensitivity analysis will thus reflect the impact of a hypothetical future wind and solar energy system.

\section{RESULTS}

5.1. LCA results

The main contributors to the overall environmental impact of the production of $2330 \mathrm{~m}^{2}$ (considering a grammage of $360 \mathrm{~g} / \mathrm{m}^{2}$ ) of technical textile issued from one hectare of cultivated flax, are the processes of weaving, spinning, flax cultivation, retting, the avoided glass fiber production, the woody residues combustion and, to a lower extent, the induced land use change (iLUC) (Figure 3).

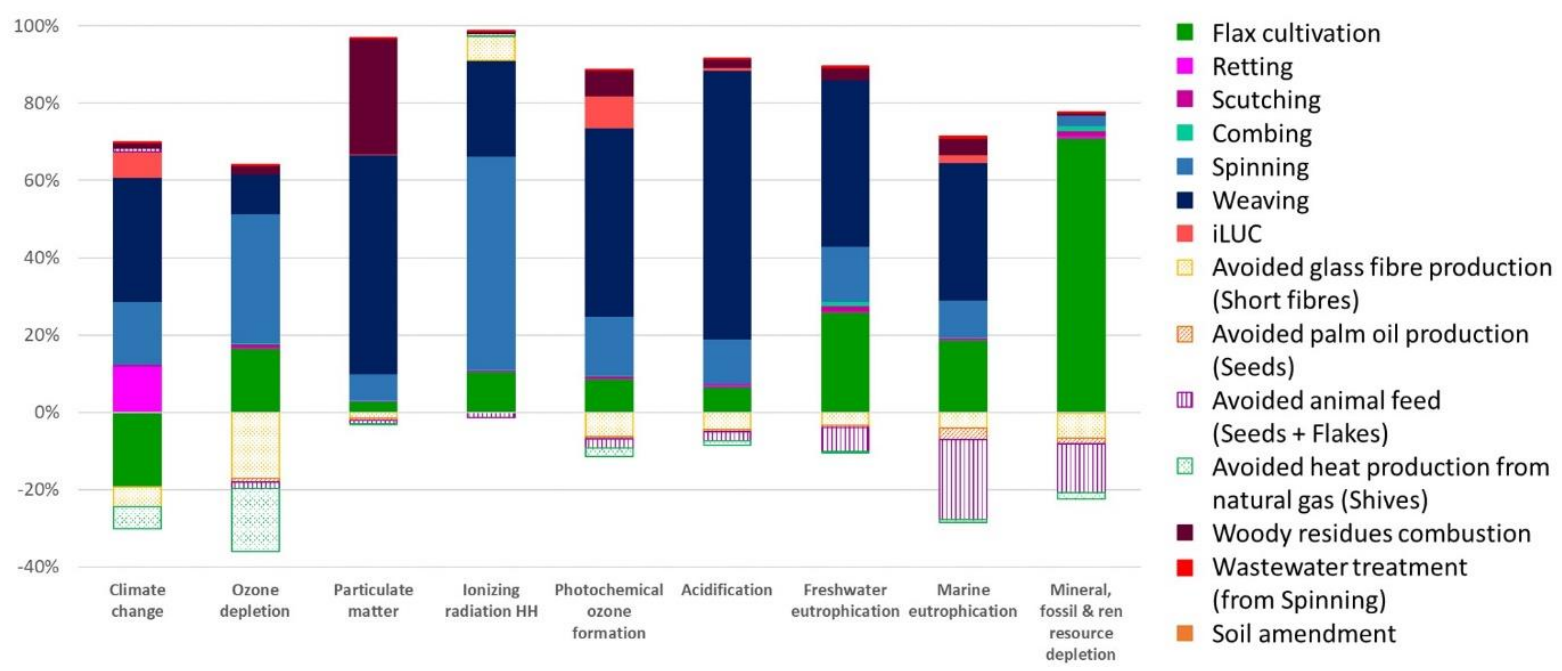

Figure 3. Processes contribution to generated (positive values) and avoided (negative values) environmental impacts in the production of a flax fiber technical textile from 1 ha of cultivated land

Moreover, Figure 3 illustrates the generated (positive values) as well as avoided (negative values) impacts, broken down at the process level. The absolute values behind Figure 3 are presented in Table 3.

Table 3. Results of the environmental impact of producing flax fiber technical textile issued from one ha of cultivated land

\begin{tabular}{|l|r|r|l|}
\hline \multicolumn{1}{|c|}{ Impact category } & \multicolumn{1}{c|}{ Total/ha } & \multicolumn{1}{c|}{$\begin{array}{c}\text { Total/m } \mathbf{m}^{\mathbf{2}} \text { of } \\
\text { technical textile }\end{array}$} & \multicolumn{1}{c|}{ Unit } \\
\hline Climate change & 18162 & 7.79 & $\mathrm{~kg} \mathrm{CO} 2 \mathrm{eq}$ \\
\hline Ozone depletion & $3.6 \times 10^{-4}$ & $1.55 \times 10^{-7}$ & $\mathrm{~kg} \mathrm{CFC}-11 \mathrm{eq}$ \\
\hline Particulate matter & 52 & 0.02 & $\mathrm{~kg} \mathrm{PM} 2.5 \mathrm{eq}$ \\
\hline Ionizing radiation & 1048 & 0.45 & $\mathrm{kBq} \mathrm{U235} \mathrm{eq}$ \\
\hline Photochemical ozone formation & 87 & 0.04 & $\mathrm{~kg} \mathrm{NMVOC} \mathrm{eq}$ \\
\hline Acidification & 194 & 0.08 & $\mathrm{molc} \mathrm{H}+\mathrm{eq}$ \\
\hline Freshwater eutrophication & 4.5 & $1.2 \times 10^{-3}$ & $\mathrm{~kg} \mathrm{P} \mathrm{eq}$ \\
\hline Marine eutrophication & 23 & $9.8 \times 10^{-3}$ & $\mathrm{~kg} \mathrm{~N} \mathrm{eq}$ \\
\hline Mineral, fossil \& renewable resource depletion & 0.48 & $2.1 \times 10^{-4}$ & $\mathrm{~kg} \mathrm{Sb} \mathrm{eq}$ \\
\hline
\end{tabular}


To better understand the causes and substances behind the environmental impacts (generated or avoided), each of the processes identified as main contributors were analyzed individually, as shown in Figure 4 to Figure 10.

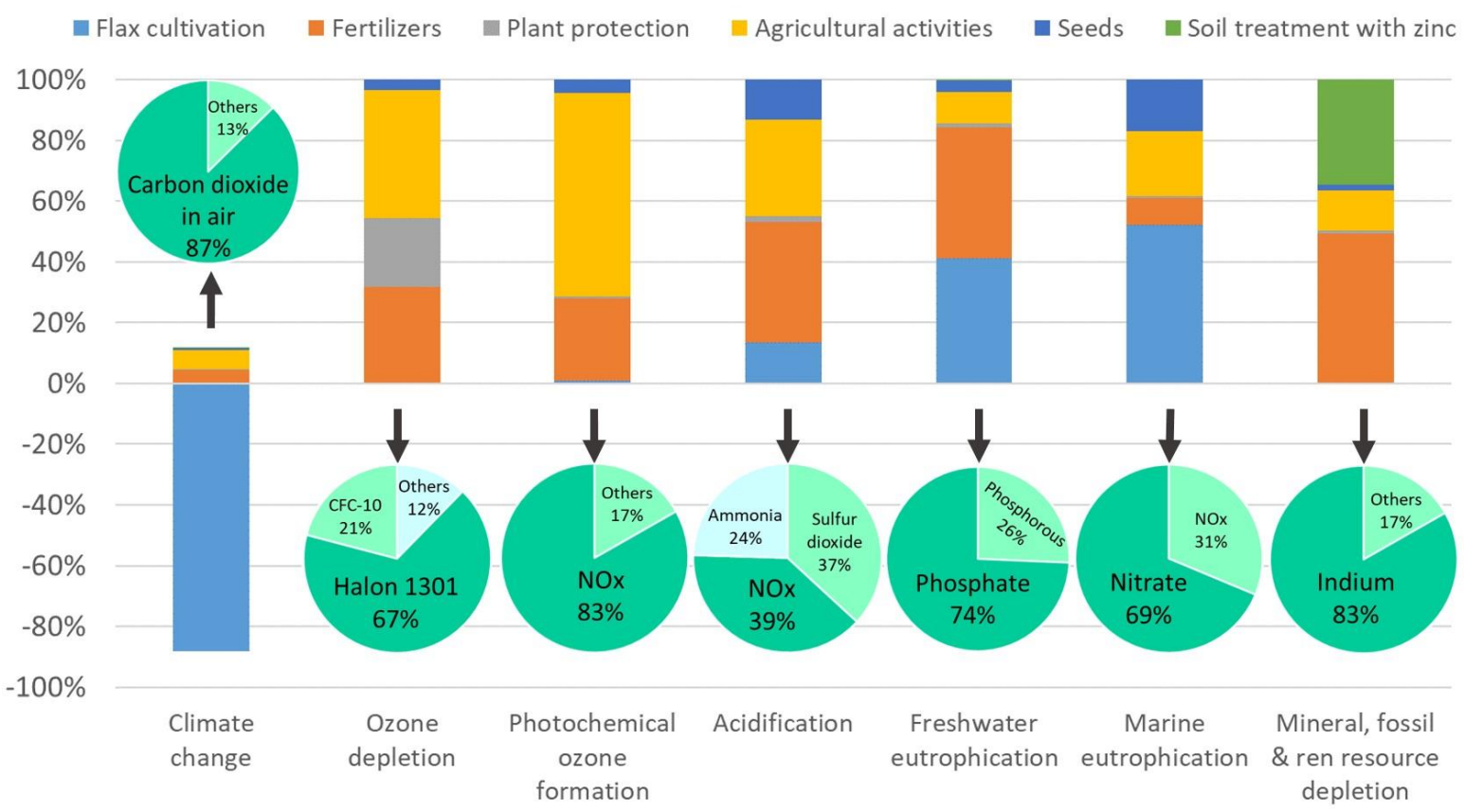

Figure 4. Flax cultivation - Individual analysis of the main induced and avoided environmental impacts and the substances responsible

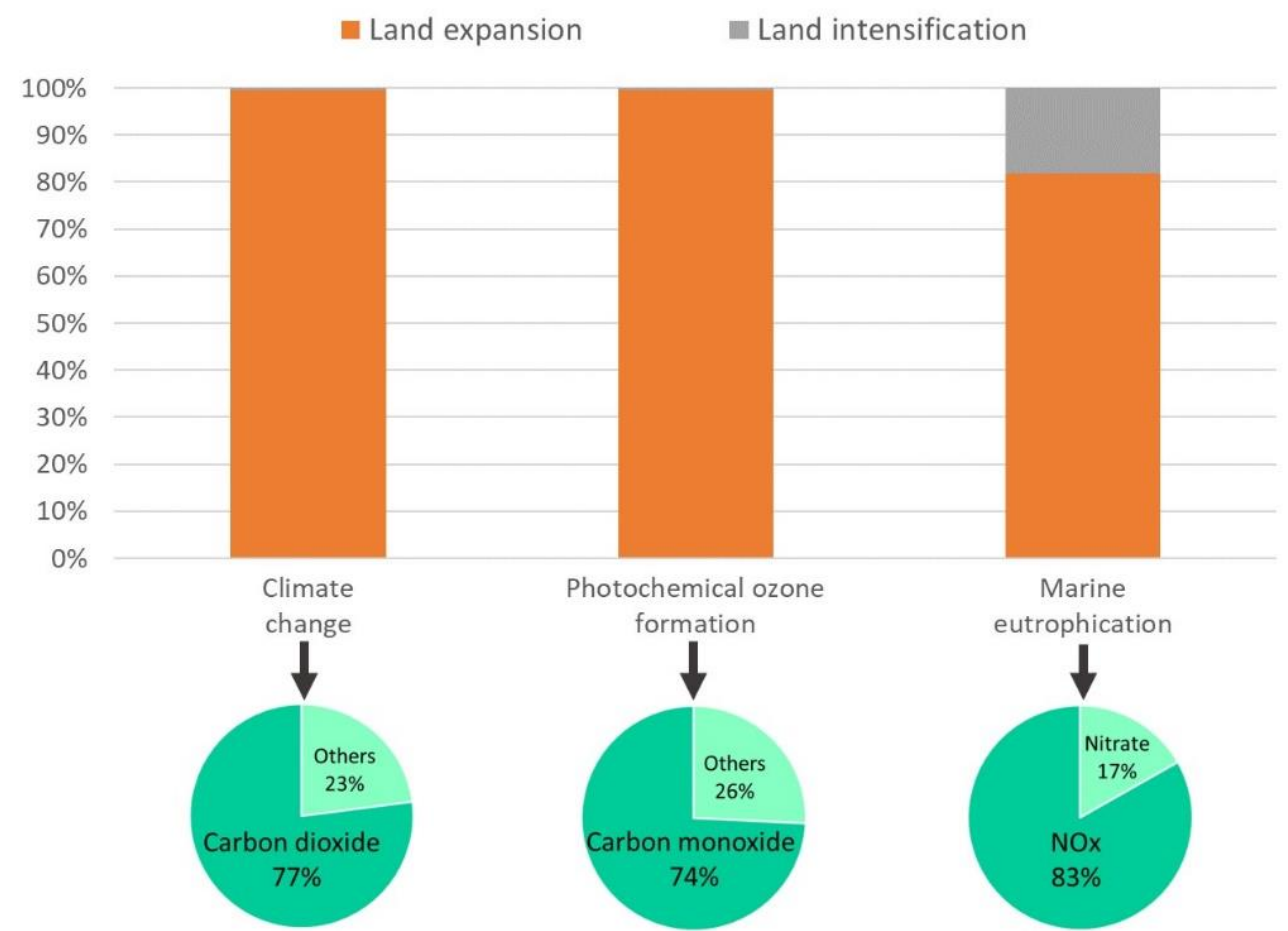

Figure 5. iLUC- Individual analysis of the main environmental impacts and the substances responsible 

- Lubricating oil production
- Transport by land
- Transport by sea (France to China)
- Electricity (China)
- Natural Gas (in China)

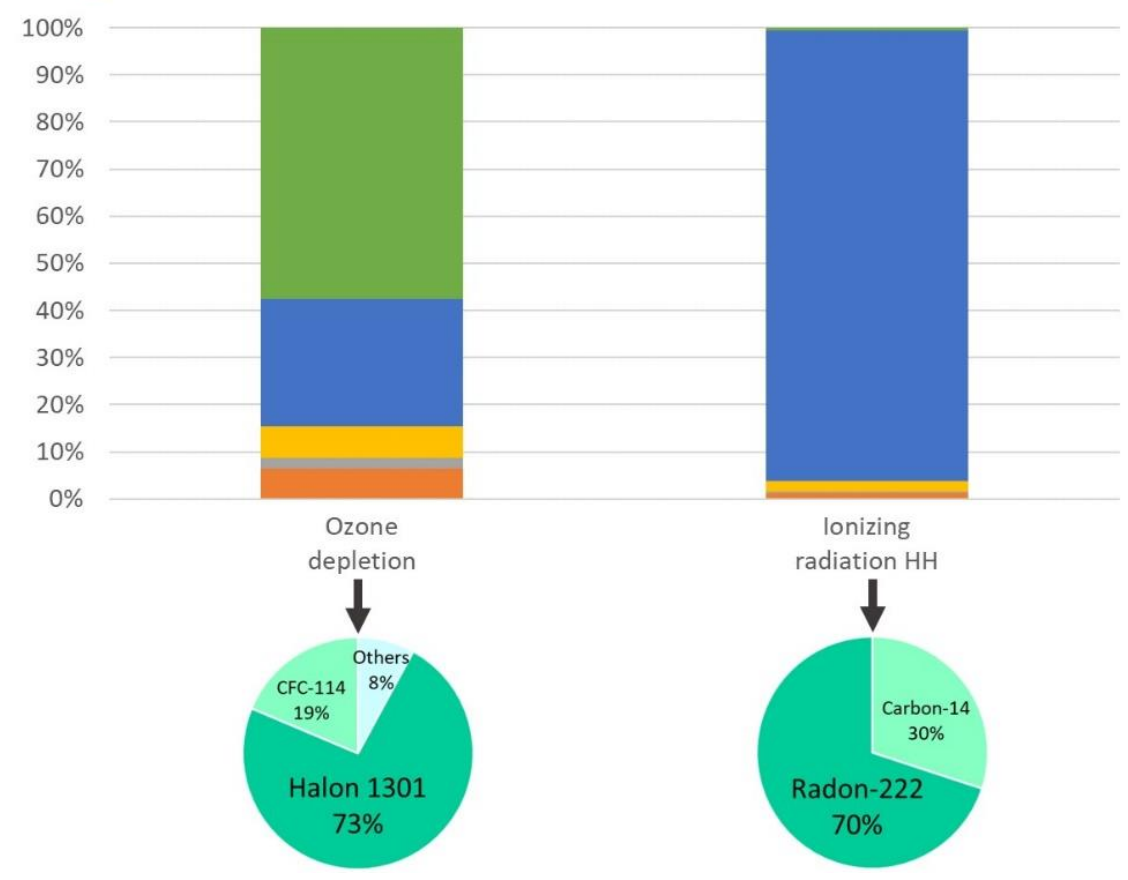

Figure 6. Spinning - Individual analysis of the main induced environmental impacts and the substances responsible

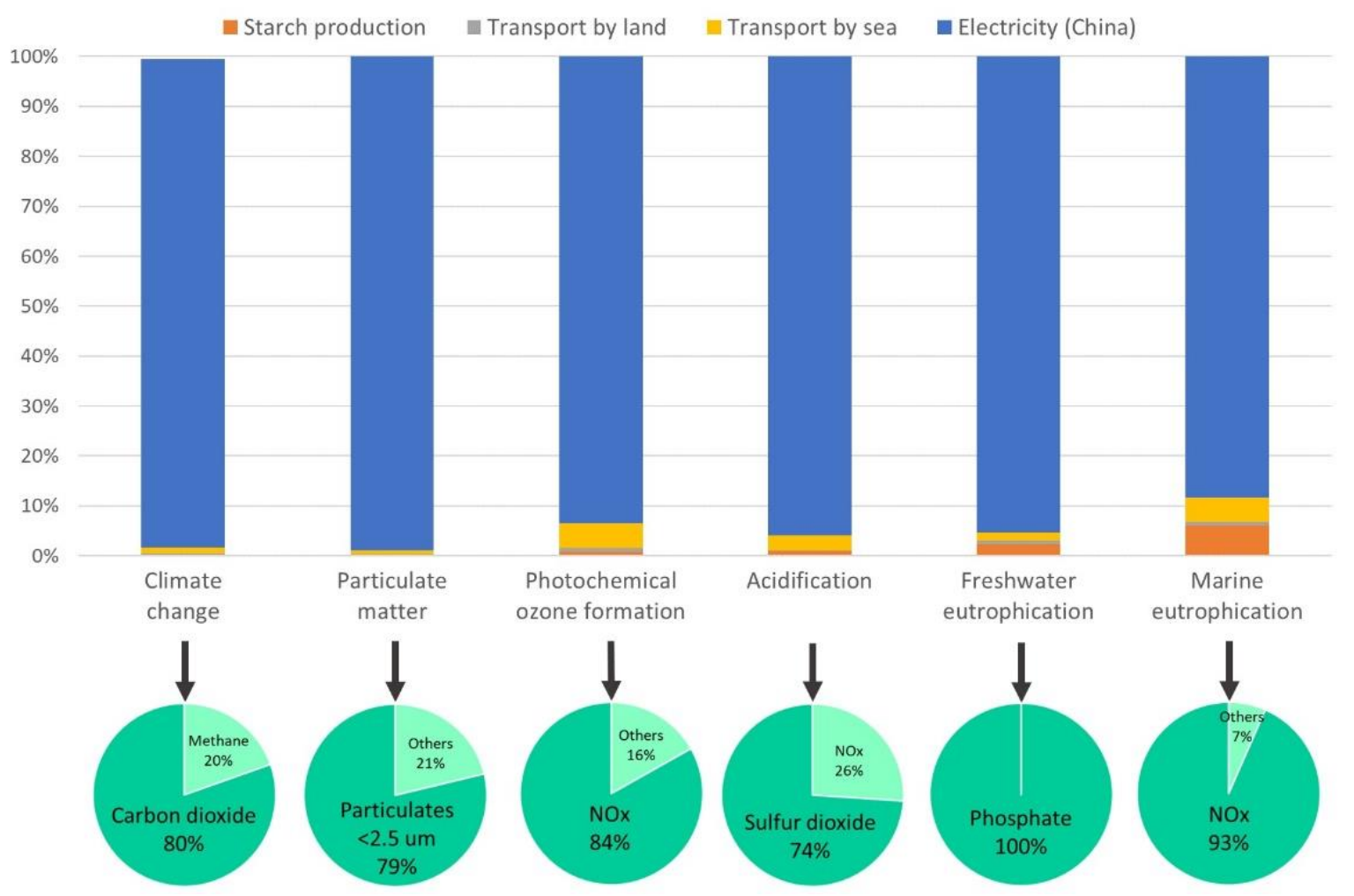

Figure 7. Weaving - Individual analysis of the main environmental impacts and the substances responsible 


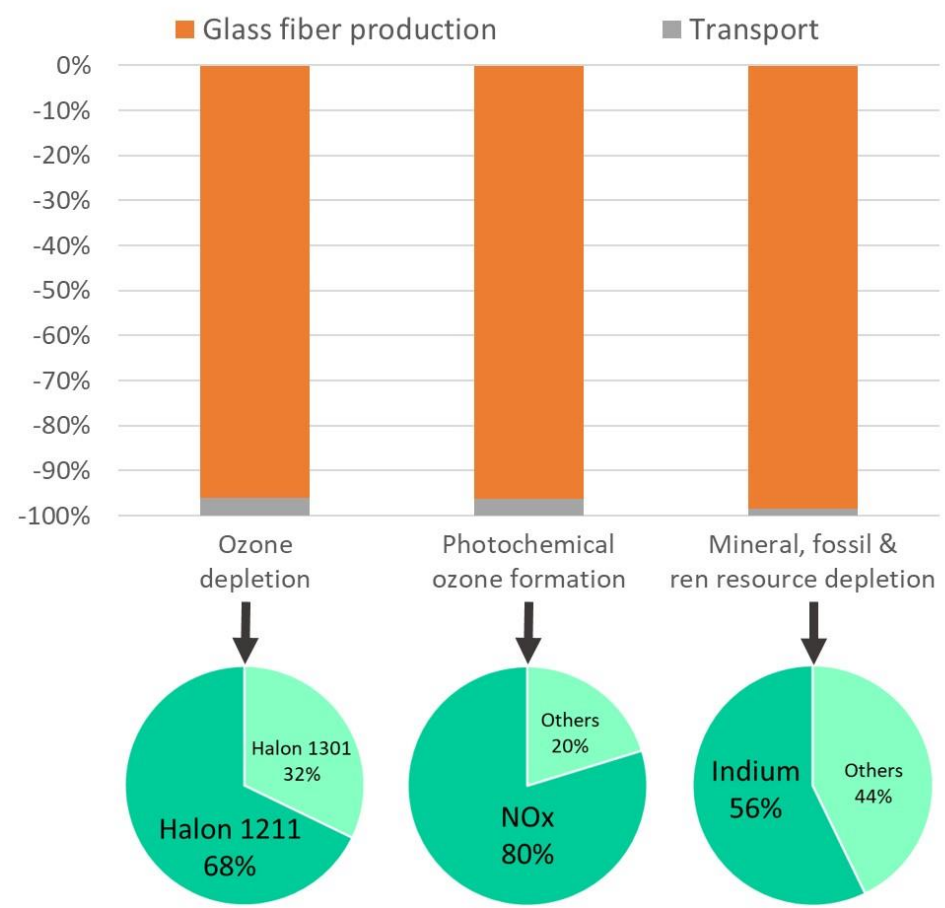

Figure 8. Avoided production of glass fiber - Individual analysis of the main avoided environmental impacts and the substances responsible

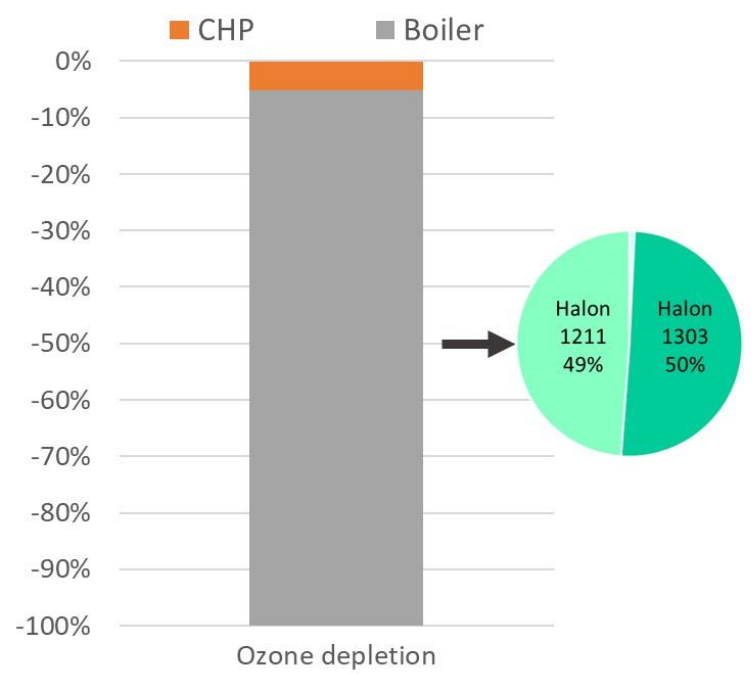

Figure 9. Avoided heat production from natural gas - Individual analysis of the main avoided environmental impact and the substances responsible 


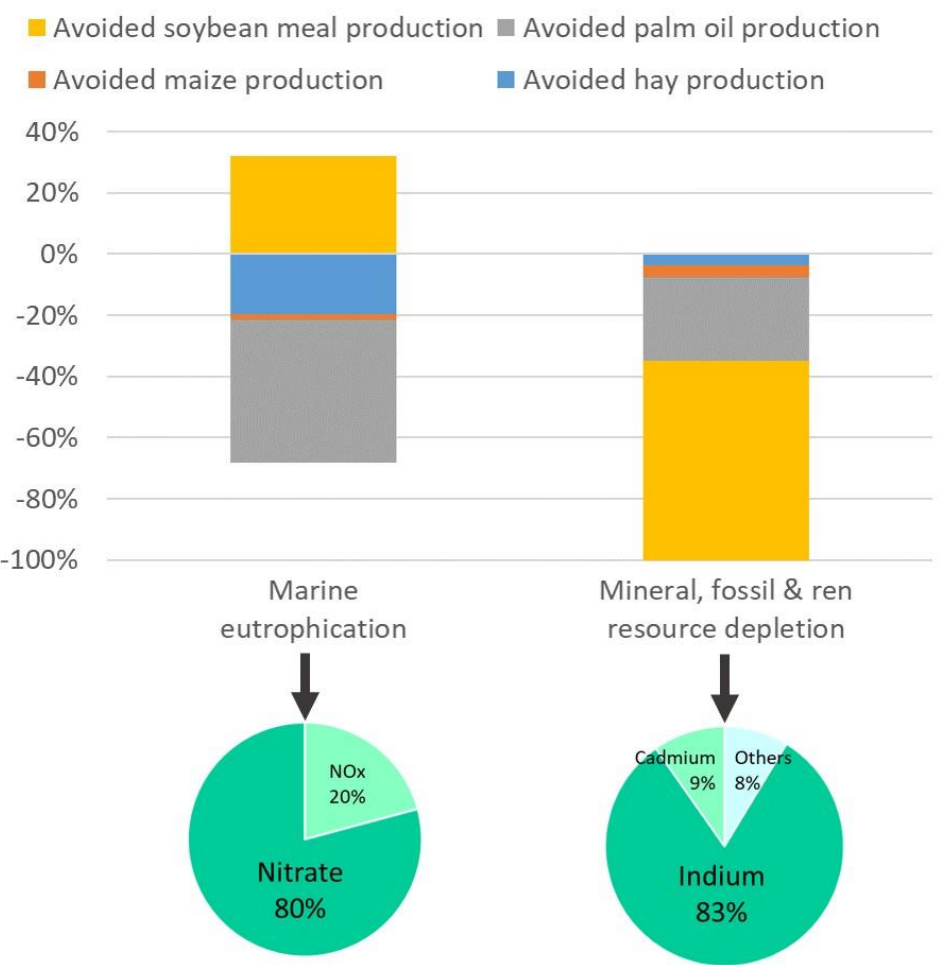

Figure 10. Avoided animal feed production - Individual analysis of the main avoided environmental impact and the substances responsible

In general, results show that:

- The spinning and weaving processes represent between $45 \%$ and $95 \%$ of the generated environmental impact in all of the categories except for Mineral, fossil \& renewable resources depletion.

- The combustion of woody residues has higher or almost equivalent environmental impact than the benefits generated by the fossil-based heat it avoids (avoided heat production from natural gas). This is particularly true for the impact category Particulate matter. However, wood-based heat (rather than natural gas heat) contributes to the reduction of Ozone depletion and Climate change, as well as Photochemical ozone formation and Acidification, to a lower extent.

- A contribution of the induced land use change (iLUC) to the impact category Climate change is visible and, to a lower extent, to the impacts Photochemical ozone formation, Acidification and Marine eutrophication.

- The avoided glass fiber production (due to the generation of short fibers as a co-product in the scutching process) translates into avoiding impacts (i.e. negative values), even if small, in all the environmental categories assessed, except for lonizing radiation $\mathrm{HH}$ where a generated (or positive) impact is clearly visible.

- The avoided animal feed resulting from the valorization of seeds and flakes (scutching process), results in avoided impacts for Freshwater and Marine eutrophication, as well as Acidification and Mineral, fossil $\&$ renewable resource depletion. A contribution to a reduction in the impacts lonizing radiation and Photochemical ozone formation is also visible, even if lower. 
- In the totality of the system, ten substances were identified as the main cause of the generated environmental impacts. These substances (and their cause) being: Carbon dioxide (iLUC, Chinese electricity), Halon 1301 (flax cultivation; Chinese electricity), Particulate matter <2.5 um (Electricity in China), Radon-222 (Electricity in China), Carbon monoxide (iLUC), Nitrogen oxides (flax cultivation; Chinese electricity; iLUC), Sulphur dioxide (Chinese electricity), Nitrate (flax cultivation), Phosphate (flax cultivation; Chinese electricity) and Indium depletion (flax cultivation).

- Finally, the avoided environmental impacts were mainly due to the avoidance of using or generating the following substances: Halon 1211 \& 1301, Indium, Nitrates and Carbon dioxide uptake during flax cultivation (the LCl being cradle-to-gate).

\subsection{Sensitivity Analysis (SA)}

Figure 11 shows the impacts of an all-French electricity production and use (i.e. no use of the Chinese electricity mix). It highlights that using $100 \%$ French electricity rather than a mix of the French and Chinese electricity would be beneficial for every impact category, except for Ozone depletion and Mineral, fossil \& renewable resources depletion.

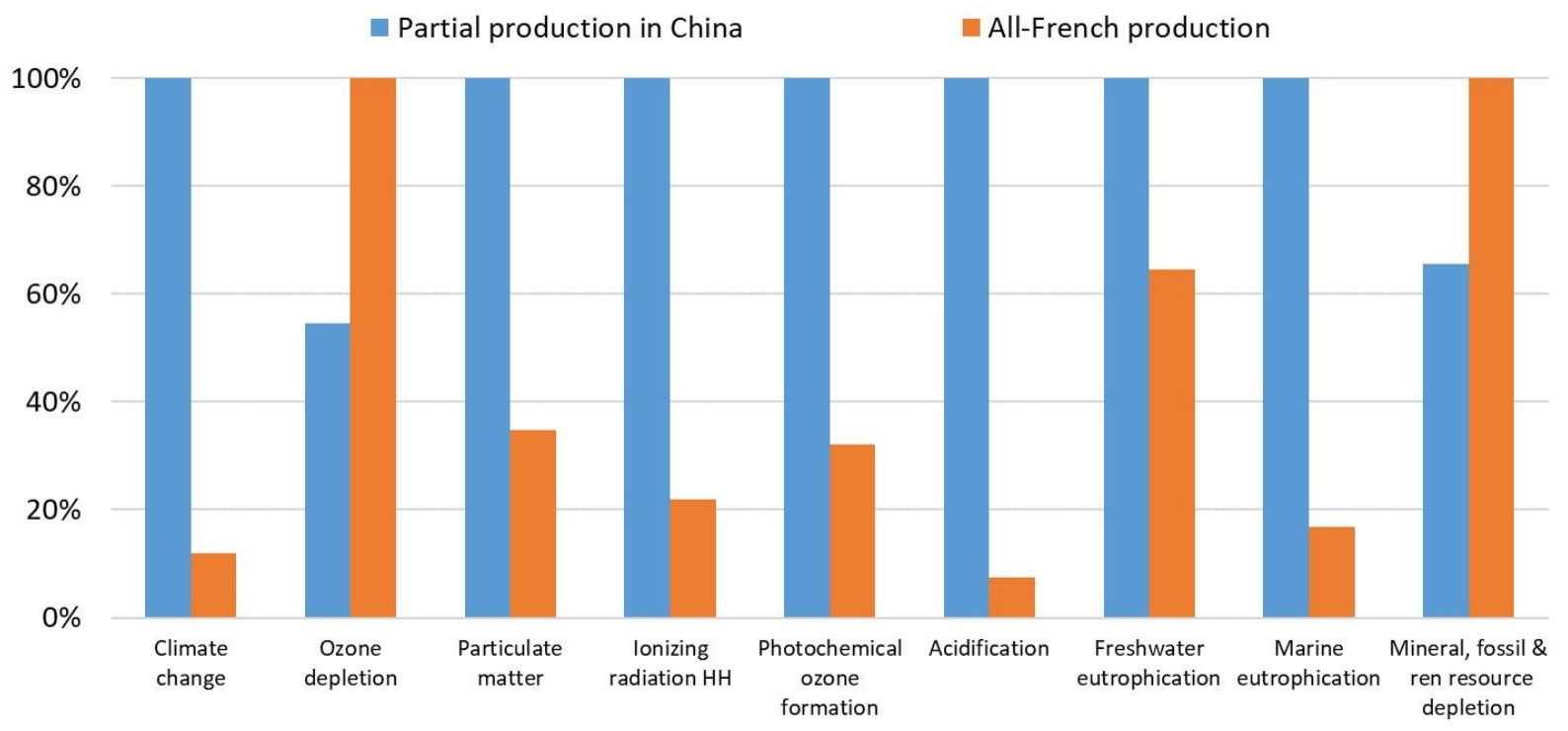

Figure 11. Sensitivity Analysis for production considering different electricity mixes

Nowadays, given its installed capacities and production prices, the production of textile products is most likely to be outsourced to China. However, France counts with the technology to locally produce a flax fiber technical textile. Through Figure 11, it is visible that an all-French supply chain would result in a more performant product, from an environmental point of view.

\section{DISCUSSION}

Flax cultivation is a process that both generates and avoids environmental impacts (Figure 4). Generated impacts are significant for Freshwater and Marine eutrophication, Ozone depletion and for Mineral, fossil \& renewable 
resources depletion; mainly due to fertilizers and zinc for soil treatment. For instance, the production of triple superphosphate fertilizer (35\%; essentially due to discharges to water compartments) and its application on the field (40\%; process detailed in the SI) induces freshwater eutrophication due to leakage of phosphates and phosphorous to water sources. Moreover, the production of the same fertilizer along with zinc used for soil treatment after sowing, causes a depletion of resources as the infrastructure for mines induces an exhaustion of substances such as indium and cadmium. Over $60 \%$ of the impact on Mineral, fossil \& renewable resources depletion is in fact due to flax cultivation, and of this almost $50 \%$ is due to triple superphosphate and $35 \%$ to zinc.

Results show a high relation between zinc procurement and the depletion of indium, which is the main responsible for the impact on Mineral, fossil \& renewable resources depletion. This is due to the fact that indium is a by-product of zinc extraction, along with other substances such as cadmium (Classen et al. 2009).

Ozone depletion is caused mainly by Halons and CFCs, these substances are linked to the distribution of fossilbased fuels and the production of plant protection products (bentazone, specifically). Halon gases are used as fire retardant agents in pipelines; the Ecoinvent processes for fossil-based fuels (i.e. diesel and natural gas) consider emissions of halon gases to air to be caused by accidents and values were estimated from corporative environmental reports (Faist Emmenegger et al. 2007).

The $\mathrm{NO}_{\mathrm{x}}$ emissions responsible for the Photochemical ozone formation and Acidification impacts are as well consequences of the use fossil-based energy sources in the production of fertilizers (namely, nitrogen and phosphate fertilizers) and used in agricultural activities (i.e. plowing).

Marine eutrophication is essentially due to the procurement of seeds. The impact originates from the use of nitrogen fertilizers and $\mathrm{NO}_{\mathrm{x}}$ emissions issued from the agricultural machines required for their production.

Because this analysis is cradle-to-gate, flax cultivation is here shown as a process reducing the Climate Change impact. This happens as a result of the $\mathrm{CO}_{2}$ captured by the plant during its growth; the relevance of this benefit depends upon the time the captured carbon will reside in the technosphere (e.g. as flax-based panels). A shorttime period between the sequestration of carbon and its re-emission to the atmosphere at the end-of-life phase of the panel has very little benefit and makes almost no difference in terms of long-term climate change impact (Jorgensen et al., 2015). A lifetime as long as possible as well as end-of-life solutions allowing to recycle (or maintain) the technical textile carbon within the technosphere are thus of tremendous importance to reduce the climate change impact, when the full life cycle will be considered. However, as highlighted in Figure 3, the induced demand for new arable land caused by the additional flax cultivation in France (i.e. iLUC process) reduces the global warming benefits from flax cultivation. In this study, the induced land use change represents slightly less than $10 \%$ of the impact on Climate change; which is coherent with results obtained by different authors where iLUC represents 5-20\% of the impact (Pehme et al. 2017; EC 2019; though with some outliers at almost 70\%). Figure 5 shows that the main cause of the impacts generated by the induced land use change are the effects of land expansion. Land expansion itself consists, based on the model used herein, of two processes: land clearing and foregone sequestration. Biomass burning occurring during land clearing produces $\mathrm{CO}_{2}, \mathrm{CO}$ and $\mathrm{NO}_{\mathrm{x}}$ emissions responsible for over $80 \%$ of the Climate change, Photochemical ozone formation and Marine eutrophication 
impacts. For climate change, $\mathrm{CO}_{2}$ produced during biomass burning (which alone represents over $99 \%$ of the impact) is the main contributor to the generated impact. It should be highlighted that previous studies on flax fiber as a bio-based feedstock did not include the effects of land use changes.

Deng and Tian (2015), for example, justified this omission on the premise that flax cultivation areas are currently decreasing; a premise that is obviously inconsistent with the starting point of this study, where flax is investigated as a resource to produce a new bio-based material to be introduced in the economy. The vision is thus to produce more of this material, if it is found to be a sustainable alternative to materials based on fossil-carbon. This implicitly suggests an increased demand for it and its source feedstock. In fact, flax represented about $50 \%$ of the market share in natural fibers used in the European automotive industry in 2012, and is foreseen to play a dominant role in future composite materials production (Barth and Carus 2015).

The main impact affected by the retting of flax stems was Climate change. This was caused by a background process, namely the use of agricultural machinery (i.e. rotary tedder) used for turning the stems over. Specifically, the impact is generated given the use of fossil-based fuels (i.e. diesel) as energy sources by the machinery.

As earlier stated, the spinning and weaving processes are responsible for more than $60 \%$ of the contribution to all impact categories but Mineral, fossil \& renewable resources depletion (where they represent slightly less than $3 \%$ of the impact). Electricity and heat (natural gas used in spinning) production and use are responsible for over $85 \%$ of the generated impacts by the spinning (Figure 6) and weaving (Figure 7) processes. These two processes take place in China, where almost $70 \%$ of the electricity mix comes from coal burning (hard coal) according to data from the IEA (2016a). Both the burning of coal and the activities related to its procurement have an important contribution to the overall generated impacts from Chinese electricity, in all categories. Impacts are, however, exacerbated by the fact that the Ecoinvent process considers hard coal to be about $75 \%$ of China's source of electricity.

Moreover, Dissanayake et al. (2009) also identified spinning as a hot spot. These authors pointed out that avoiding that process, if possible, is an opportunity for reducing energy consumption. In fact, on the basis that the spinning process might diminish the mechanical properties of fibers, Le Duigou et al. (2011) did not take it into consideration in their LCA. However, their final composite material products consider as reinforcement a flax mat where fibers are randomly dispersed, so there is no need for them to be spun or woven. Bachmann et al. (2018), whom studied the impact of various "novel sustainable panels" for the aviation sector, did consider spinning in their LCl of flax yarn production. Impacts to Ozone depletion are a consequence of the procurement (on-shore extraction) of fossil-based energy sources (i.e. natural gas) used during the spinning process. This is due to the use of substances such as Halon 1301 and 1211; used as fire suppression agents in oil pipelines (UNEP HTOC 2014). Figure 6 and Figure 7 as well show that impacts from transportation are negligible when compared to those issued from electricity procurement. This means that the degree of the impact of outsourcing production depends more on the way countries produce electricity than the distances between them or the energy source used by the transportation vessels. 
Furthermore, the valorization of the co-produced short fibers as a reinforcement component in composite materials results in a diminishment of the production of glass fiber. This, in turn, translates in avoided impacts Ozone depletion, Photochemical ozone formation and Mineral, fossil \& renewable resources depletion, predominantly. This is mainly due to the avoided consumption of Halon 1211 and Indium as well as a reduction of $\mathrm{NO}_{\mathrm{x}}$ emissions (Figure 8); the impact of Halon 1211 is due to the use of fossil-based energy use in the production of glass fibers as it is used as a fire suppression agent (as previously stated). Moreover, the use of Indium is related to the mining of zinc (as for the flax cultivation process), which is used for the coating of steel coils required for the construction of glass fiber factories. $\mathrm{NO}_{\mathrm{x}}$ emissions come from electricity production in the Asian markets. The advantages of using natural fibers as reinforcement materials instead of glass fibers have also been proven on various occasions by different authors (Akhshik et al. 2017; Corbiere-Nicollier et al. 2001).

The most visible benefit of avoiding heat production from natural gas is the decrease on the use of Halon 1211 and Halon 1303 (Figure 9); which, as previously mentioned, are used in pipelines as fire suppressant agents and contribute to the depletion of the ozone layer. These are directly related to the transportation of natural gas in pipelines.

On the other hand, the avoided heat production from natural gas generates impact on lonizing radiation. This is due to the fact that the process used to model the avoided heat production from natural gas (consequential process from Ecoinvent v3.4) considers that producing heat from natural gas through a co-generation plant in Europe reduces the use of current European marginal electricity. By no longer using natural gas, that marginal European electricity is no longer avoided (by the no longer co-generated electricity). Further analysis led to the identification of Radon-22 to be the main cause of the impact. As Radon-22 is a gas resulting from the radioactive decay of Uranium, it leads to the conclusion that no longer producing heat from natural gas increases the use of nuclear power. This was corroborated by an analysis of the Ecoinvent v3.4 process for heat production from natural gas, which considers that electricity produced from co-generation, reduces the use of nuclear power. The same analysis applies for the avoided glass fiber production where the generated impact on lonizing radiation is much more visible. In fact, the Ecoinvent process used to model glass fiber production considers an important use of co-generated natural gas heat.

The most visible impact generated by the woody residues combustion is the generation of particulate matter, a well-documented issue of biomass combustion (Keller and Burtscher 2017; Nyström et al. 2017; Dasch 2002), which displays a much more complex chemical composition than natural gas.

The major impacts affected by the avoided animal feed production are Marine eutrophication and Mineral, fossil \& renewable resources depletion (Figure 10). The impact on the former is essentially explained by the avoidance of nitrate emissions from the avoided hay and palm oil production. Agricultural activities are linked to the procurement of zinc; it being closely tied to indium mining, leads to the decrease of the Mineral, fossil \& renewable resources depletion impact. Figure 10 further highlights that the avoided soybean meal production increases the Marine eutrophication impact. This is explained by the work of Dalgaard et al. (2008) where it is demonstrated that an increase in demand for soybean meal affects the production of palm oil, thus creating 
what they refer to as a soybean loop. In other words, the avoidance of soybean meal implies less oil production; palm oil production will thus react to this oil shortage. Therefore, nitrates emitted from the cultivation of palm are the substances responsible for the Marine eutrophication caused by the avoided soybean meal production. It should also be noted that the avoided soybean meal may have been slightly overestimated. In fact, the substitution considered here was made on the basis of crude protein content. Yet, in terms of protein, it is rather the quality that counts, and more precisely the quantity of essential amino acids.

When comparing scenarios for a production with the spinning and weaving processes carried out with different electricity mixes, results favored a production with the French electricity mix (Figure 11). This result is coherent with the results obtained by Deng and Tian (2015) when comparing different electricity supply mixes for producing a composite material with flax as reinforcement. Nonetheless, a partial production in China appears more favorable for two impacts, namely for Ozone and Mineral, fossil \& renewable resources depletion. For the former, this is due to an increased use of Halon 1211, as the French electricity induces the use of natural gas as source of energy. Meanwhile, the higher impact on Mineral, fossil \& renewable resources depletion reflects the higher solar power used in the French electricity mix (making ca. $45 \%$ of the mix against $<1 \%$ in China) and thus resources for photovoltaic panels. A higher impact in lonizing radiation could have been expected for the French electricity mix, given the high percentage of nuclear energy in France (72\% of all electricity demand in 2016; IEA 2016). However, this study is consequential and considers the processes that can react as a result of a demand change. Nuclear energy can hardly react to an increased demand for electricity, among others because of the long lag between the decision to establish a new capacity and the moment where the plant is fully operational (Moora and Lahtvee 2009), and because of a legal ceiling on installed nuclear capacity in the specific case of France (EC 2018a). In fact, the low voltage French electricity mix processes used herein (consequential process retrieved from Ecoinvent v3.4) does not include nuclear energy (but rather a high percentage of solar power, as earlier mentioned).

\section{CONCLUSIONS}

Through a cradle-to-gate LCA, the environmental performance of a flax-based technical textile was assessed. The presented consequential life cycle inventory aims to (but not limited to) be used by LCA practitioners and interested parties for performing LCA for comparing the environmental impact of products with one of their components being flax fiber. The proposed $\mathrm{LCl}$ allows for future assessments to be carried out considering either the whole supply chain of production and transformation of flax or with focus on specific processes, depending on specific system boundaries and the product of interest (i.e. short fibers). Efforts focused on presenting information in a clear and concise fashion for modifications to be easily made, allowing a better representation of a broad spectrum of scenarios as agricultural practices and market trends might evolve.

The herein presented work improved existing LCAs on flax fiber production by the inclusion of the emissions issued from the retting process, the valorization of co-products (through system expansion), and the analysis of more impact categories than the regularly addressed in other studies (namely, climate change, ozone layer and 
abiotic depletion). Presenting a broader picture of the potential environmental impacts of using flax fiber as a source of materials.

Results show agricultural activities and electricity production (from the flax cultivation, spinning and weaving processes) to be the biggest contributors to the negative environmental performance of a flax technical textile. Very specifically for this case study, the sensibility analysis proved an all-French production to be more efficient from an environmental point of view; however China's installed capacities for fabric production and low manufacturing prices make partial production in China more attractive from a technical and economical perspective. Thus a change in production patterns (change to an all-French production) might not be completely viable. It remains, nonetheless an important factor to take into consideration and further develop as countries' relationship with renewable and fossil energies evolve.

Additionally, the impact generated by land use change from flax culture is diminished (in almost a $25 \%$ ) by the avoided land use change as a result of the valorization as animal feed of some of the co-products. Consequently, impacts being relatively small compared to those issued from electricity production and use, land use change does not represent a disadvantage for bio-based products.

The larger number of impact categories included/analyzed, contributes to a larger understanding of how coproducts might affect the environmental impact of a product. It also makes room for further analysis on different ways in which co-products can be valorized and the options that have a lower environmental impact. With this study, for example, it was made visible that the valorization of shives has a high influence on the formation of particular matter and is, therefore, an important contributor to the overall generated impact. Through this analysis, areas for improvement can be identified concerning not only the main processes but also those related to co-products. In this case, for example, the implementation of better technologies for combustion could be studied in the view of improving the environmental performance.

Moreover, the inclusion of the fate of the co-products by system expansion contributes to a more accurate assessment of the potential environmental impacts. Otherwise, the impact on categories such as Ozone depletion and Marine eutrophication would have been largely overestimated; while impacts concerning Particulate matter and lonizing radiation, underestimated. Given that a consequential approach was taken for this study, decisions aiming to improve the environmental performance of a flax fiber technical textile can be made having a clearer, more close to reality point of view.

Overall, this study shows the relevance of taking into consideration a country's energy mix and the geographical scope of a product's life cycle as it has important impact on its environmental performance. Moreover, when considering the fate of co-products, the valorization they are given plays as well a very important role as they will not forcibly generate a benefit but it was proven that they can contribute to an increase of the impact on different categories. Therefore, correctly defining the former becomes as crucial a factor as having a complete and precise life cycle inventory. 


\section{ACKNOWLEDGMENTS}

The work was carried out as part of the doctoral thesis of A. Gomez-Campos, her work being financed by a scholarship awarded by the French Ministry of Higher Education, Research and Innovation (Ministère de I'Enseignement supérieur, de la Recherche et de l'Innovation in French).

The research leading to these results has received funding from ADEME under the grant agreement $\mathrm{n}^{\circ} 1501 \mathrm{C0050}$. The time used by L. Hamelin during this research was funded by the Cambioscop project, supported by the French National Research Agency, Programme Investissement d'Avenir (ANR-17-MGPA-0006). 


\section{REFERENCES}

ADEME, and ITCF. 1998. "Etude Agrice - Lin Fibre." https://www.doc-developpementdurable.org/file/Culture-plantes-a-fibres/lin/lin\%20fibre.pdf.

Akhshik, M., Panthapulakkal, S., Tjong, J., and Mohini, S. 2017. "Life Cycle Assessment and Cost Analysis of Hybrid Fiber-Reinforced Engine Beauty Cover in Comparison with Glass Fiber-Reinforced Counterpart." Environmental Impact Assessment Review 65 (July): 111-17. https://doi.org/10.1016/j.eiar.2017.04.005.

Bachmann, J., Hidalgo, C., and Bricout, S. 2017. "Environmental Analysis of Innovative Sustainable Composites with Potential Use in Aviation Sector-A Life Cycle Assessment Review." Sci China Technol Sc 60 (9): 1301-17. https://doi.org/10.1007/s11431-016-9094-y.

Barth, M., and Carus, M. 2015. "Carbon Footprint and Sustainability of Different Natural Fibres for Biocomposites and Insulation Material." nova-Institut GmbH.

Bensadoun, F., Vanderfeesten, B., Verpoest, I., Van Vuure, A.W., and Van Acker, K. 2016. "Environmental Impact Assessment of End of Life Options for Flax-MAPP Composites." Ind Crop Prod 94 (December): 32741. https://doi.org/10.1016/j.indcrop.2016.09.006.

BIOIntelligence Service. 2007. “Analyse de Cycle de Vie Comparée d'une Chemise En Lin et d'une Chemise En Coton." Organisations professionnelles du lin.

Bleuze, Laurent. 2019. "Rouissage Au Sol Du Chanvre Industriel (Cannabis Sativa I): Dynamique Sous Environnement Contrôlé et Modélisation."

Boutin, M., Flamin, C., Quinton, S., Gosse, G., and INRA Lille. 2005. "Étude Des Caractéristiques Environnementales Du Chanvre Par l'analyse de Son Cycle de Vie." Ministère de l'agriculture et de la pêche.

Brandão, M., Martin, M., Cowie, A., Hamelin, L., and Zamagni, A. 2017. Consequential Life Cycle Assessment: What, How, and Why?

C.E.L.C. 2010a. "Le Lin et Le Chanvre Européen." Masters of Linen. 2010. http://mastersoflinen.com/fre/lin/19-la-carte-du-lin__.

C.E.L.C. 2010b. "Le Lin et Le Chanvre Européen." Schéma Du Lin. 2010. http://mastersoflinen.com/fre/lin/7schema-du-lin

Chandrasekaran, M. 2013. Valorization of Food Processing By-Products. Fermented Foods and Beverages Series. Boca Raton, Fla.: CRC Press.

Classen M., Althaus H.-J., Blaser S., Tuchschmid M., Jungbluth N., Doka G., Faist Emmenegger M. and Scharnhorst W. (2009) Life Cycle Inventories of Metals. Final report Ecoinvent data v2.1, No 10. EMPA Dübendorf, Swiss Centre for Life Cycle Inventories, Dübendorf, $\mathrm{CH}$.

Corbiere-Nicollier, T., Gfeller-Laban, B., Lundquist, L., Leterrier, Y., Manson, J. a. E., and Jolliet, O. 2001. "Life Cycle Assessment of Biofibres Replacing Glass Fibres as Reinforcement in Plastics." Resour Conserv Recy 33 (4): 267-87.

Dalgaard, R., Schmidt, J., Halberg N., Christensen, P., Thrane, M., and Pengue, W.A.. 2008. "LCA of Soybean Meal." Int J Life Cycle Ass 13 (3): 240-54. https://doi.org/10.1065/lca2007.06.342.

Dasch, J. M. 2002. "Particulate and Gaseous Emissions from Wood-Burning Fireplaces." May 1, 2002. https://doi.org/10.1021/es00104a003.

Deng, Y., and Tian, Y. 2015. "Assessing the Environmental Impact of Flax Fibre Reinforced Polymer Composite from a Consequential Life Cycle Assessment Perspective." Sustainability-Basel 7 (9): 11462-83. https://doi.org/10.3390/su70911462. 
Dissanayake, N. P. J., Summerscales, J., Grove, S. M., and Singh, M. M. 2009. "Energy Use in the Production of Flax Fiber for the Reinforcement of Composites." J Nat Fibers 6 (4): 331-46. https://doi.org/10.1080/15440470903345784.

Earles, J. M., and Halog, A. 2011. "Consequential Life Cycle Assessment: A Review." Int J Life Cycle Ass 16 (5): 445-53.

EC. 2013. "Commission Recommendation of 9 April 2013 on the Use of Common Methods to Measure and Communicate the Life Cycle Environmental Performance of Products and Organisations."

EC. 2017. "PEFCR Guidance Document - Guidance for the Development of Product Environmental Footprint Category Rules (PEFCRs), Version 6.3."

EC. 2018. "A Clean Planet for All - A European Strategic Long-Term Vision for a Prosperous, Modern, Competitive and Climate Neutral Economy." https://ec.europa.eu/clima/sites/clima/files/docs/pages/com_2018_733_en.pdf.

EC. 2018. "Bio-Based Products." November 2018. http://ec.europa.eu/growth/sectors/biotechnology/biobased-products_en.

EC. 2019. "Environmental Impact Assessments of Innovative Bio-Based Product. Task 1 of "Study on Support to R\&I Policy in the Area of Bio-Based Products and Services"." https://publications.europa.eu/en/publication-detail/-/publication/15bb40e3-3979-11e9-8d04-

01aa75ed71a1/language-en.

Ekvall, T., Azapagic, A., Finnveden, G., Rydberg, T., Weidema, B. P., and Zamagni, A. 2016. “Attributional and Consequential LCA in the ILCD Handbook." Int J Life Cycle Ass 21 (3): 293-96. https://doi.org/10.1007/s11367-015-1026-0.

Embassy of France in Washington. 2018. "National Action Plan for Bioeconomy Announced." French Food in the US - The Agriculture Department. March 2018. https://frenchfoodintheus.org/3809.

Ewertowska, A., Galán-Martín, A., Guillén-Gosálbez, G., Gavaldá, J., and Jiménez, L. 2016. “Assessment of the Environmental Efficiency of the Electricity Mix of the Top European Economies via Data Envelopment Analysis." J Clean Prod 116 (C): 13-22. https://doi.org/10.1016/j.jclepro.2015.11.100.

Faist Emmenegger M., Heck T., Jungbluth N., Tuchschmid M. (2007) Erdgas. In: Sachbilanzen von Energiesystemen: Grundlagen für den ökologischen Vergleich von Energiesystemen und den Einbezug von Energiesystemen in Ökobilanzen für die Schweiz (ed. Dones R.). Swiss Centre for Life Cycle Inventories, Dübendorf, $\mathrm{CH}$.

FAOSTAT. 2017. “Crops.” 2017. http://www.fao.org/faostat/en/?\#data/QC.

Finnveden, G., Hauschild, M. Z., Ekvall, T., Guinée, J., Heijungs, R., Hellweg, S., Koehler, A., Pennington, D., and Suh, S. 2009. "Recent Developments in Life Cycle Assessment." J Environ Manage 91 (1): 1-21. https://doi.org/10.1016/j.jenvman.2009.06.018.

GNIS. 2018a. “Glossaire Du Lin I Le Lin Côté Nature.” 2018. https://www.lelincotenature.fr/ajax_getDefinition.php?id_definition=2.

GNIS. 2018b. “Le Rouissage de Lin, Une Opération Délicate.” Le Lin Côté Nature. 2018. https://www.lelincotenature.fr/FR/Le-rouissage-du-lin-une-operation-delicate-166.html.

Hamelin, L. 2013. "Carbon Management and Environmental Consequences of Agricultural Biomass in a Danish Renewable Energy Strategy." PhD Thesis, Odense, Denmark: University of Southern Denmark.

Hamelin, L., Naroznova, I., and Wenzel, H. 2014. "Environmental Consequences of Different Carbon Alternatives for Increased Manure-Based Biogas." Appl Energ 114 (February): 774-82. https://doi.org/10.1016/j.apenergy.2013.09.033. 
Heuzé V., Tran, G., and Lebas, F. 2015. "Flax Straw and Flax Crop By-Products." Feedipedia, a Programme by INRA, CIRAD, AFZ and FAO. 2015. https://www.feedipedia.org/node/132.

IEA. 2016. "Statistics | France - Total Primary Energy Supply (TPES) by Source (Chart)." 2016. https://www.iea.org/statistics/?country=FRANCE\&year=2016\&category=Key\%20indicators\&indicator=TPE SbySource $\&$ mode=chart $\&$ categoryBrowse $=$ false $\&$ dataTable=ELECTRICITYANDHEAT\&showDataTable=true .

IFM. 2004. Les données clés du textile-habillement chinois - [menaces et opportunités]. Clichy: IFM-Ctoe. https://data.bnf.fr/fr/12007583/centre_textile_de_conjoncture_et_d_observation_economique_france/.

IPCC. 2013. "Climate Change 2013 The Physical Science Basis - Working Group I Contribution to the Fifth Assessment Report of the Intergovernmental Panel on Climate Change." https://www.ipcc.ch/site/assets/uploads/2018/02/WG1AR5_all_final.pdf

ISO 14040. 2006. "Environmental Management - Life Cycle Assessment - Principles and Framework." https://viewer.afnor.org/Pdf/Viewer/?token=-iDSaYTKsus1.

ISO 14044. 2006. "Environmental Management - Life Cycle Assessment - Requirements and Guidelines." https://sagaweb.afnor.org/fr-FR/sw/consultation/notice/1279022?recordfromsearch=True.

Jorgensen, S. V., Hauschild, M. Z., and Nielsen, P. H. 2015. "The Potential Contribution to Climate Change Mitigation from Temporary Carbon Storage in Biomaterials." Int J Life Cycle Ass 20 (4): 451-62.

Keller, A., and Burtscher, H. 2017. "Characterizing Particulate Emissions from Wood Burning Appliances Including Secondary Organic Aerosol Formation Potential." J Aerosol Sci 114 (December): 21-30. https://doi.org/10.1016/j.jaerosci.2017.08.014.

Le Duigou, A., and Baley, C. 2014. "Coupled Micromechanical Analysis and Life Cycle Assessment as an Integrated Tool for Natural Fibre Composites Development." J Clean Prod 83 (November): 61-69. https://doi.org/10.1016/j.jclepro.2014.07.027.

Le Duigou, A., Davies, P., and Baley, C. 2011. "Environmental Impact Analysis of the Production of Flax to Be Used as Composite Material Reinforcement." J Biobased Mater Bio 5: 1-13.

Ministère de l'Agriculture et de l'Alimentation. 2018. "Une Stratégie Bioéconomie Pour La France - Plan d'action 2018-2020."

Moora, H., and Lahtvee, V. 2009. "Electricity Scenarios for the Baltic States and Marginal Energy Technology in Life Cycle Assessments - a Case Study of Energy Production from Municipal Waste Incineration." Oil Shale 26: 331-46.

Newkirk, R. 2015. “Flax Feed Industry Guide.” Winnipeg, Manitoba: Flax Canada. https://flaxcouncil.ca/wpcontent/uploads/2015/02/Flax-Feed-Industry-Guide-Final.pdf.

Nyström, R., Lindgren, R., Avagyan, R., Westerholm, R., Lundstedt, S., and Boman, C. 2017. "Influence of Wood Species and Burning Conditions on Particle Emission Characteristics in a Residential Wood Stove." Research-article. April 20, 2017. https://doi.org/10.1021/acs.energyfuels.6b02751.

Pehme, S., Veromann, E., and Hamelin, L. 2017. "Environmental Performance of Manure Co-Digestion with Natural and Cultivated Grass - A Consequential Life Cycle Assessment." J Clean Prod 162 (September): 113543. https://doi.org/10.1016/j.jclepro.2017.06.067.

Projet AF Filières. 2018. "Analyse Des Flux Des Filières Biomasse Pour Des Stratégies Régionales de Bioéconomie." Modèle Forêt-Bois 1.1 - France et Régions. September 2018. https://www.fluxbiomasse.fr/resultats/sankey_bois/France.

Santoyo-Castelazo, E., Gujba, H., and Azapagic, A. 2011. "Life Cycle Assessment of Electricity Generation in Mexico." Energy 36 (3): 1488-99. https://doi.org/10.1016/j.energy.2011.01.018. 
Schmidt, J. H., and Weidema B. P. 2007. "Shift in the Marginal Supply of Vegetable Oil." Int J Life Cycle Ass 13 (3): 235. https://doi.org/10.1065/lca2007.07.351.

Schmidt, J.H., and Muños, I.. 2014. "The Carbon Footprint of Danish Production and Consumption: Literature Review and Model Calculations." Copenhagen: Danish Energy Agency. http://vbn.aau.dk/files/196725552/_dk_carbon_footprint_20140305final.pdf.

Sharma, H.S.S., and C.F. van Sumere. 1992. The Biology and Processing of Flax. M Publications.

Sonnemann, G., and Vigon, B. 2011. Global Guidance Principles for Life Cycle Assessment LCA Databases: A Basis for Greener Processes and Products. Paris: United Nations Environment Programme (UNEP).

Tonini, D., Hamelin, L., and Astrup, T. F. 2016. "Environmental Implications of the Use of Agro-Industrial Residues for Biorefineries: Application of a Deterministic Model for Indirect Land-Use Changes." GCB Bioenergy 8 (4): 690-706. https://doi.org/10.1111/gcbb.12290.

UNEP HTOC. 2014. "Montreal Protocol on Substances That Deplete the Ozone Layer." 2014 Assessment Report 1 (2): 231-46. https://doi.org/10.1163/15718069620847781.

Vidal, R., Moliner, E., Martin, P.P., Fita, S., Wonneberger, M., Verdejo, E., Vanfleteren, F., Lapeña, N., and González, A. 2018. "Life Cycle Assessment of Novel Aircraft Interior Panels Made from Renewable or Recyclable Polymers with Natural Fiber Reinforcements and Non-Halogenated Flame Retardants: LCA of Novel Aircraft Interior Panels." J Ind Ecol 22 (1): 132-44. https://doi.org/10.1111/jiec.12544.

Weidema, B., Bauer, C., Hischier, R., Mutel, C., Nemecek, T., Reinhard, J., Vadenbo, C. O., and Wernet, G. 2013. "The Ecoinvent Database: Overview and Methodology, Data Quality Guideline for the Ecoinvent Database Version 3," 169.

Weidema, B. P., Pizzol, M., Schmidt, J., and Thoma, G. 2018. “Attributional or Consequential Life Cycle Assessment: A Matter of Social Responsibility." J Clean Prod 174 (February): 305-14. https://doi.org/10.1016/j.jclepro.2017.10.340.

Van der Werf, H. M. G., and Turunen, L. 2008. "The Environmental Impacts of the Production of Hemp and Flax Textile Yarn." Ind Crop Prod 27 (1): 1-10. https://doi.org/10.1016/j.indcrop.2007.05.003.

Wernet, G., Bauer, C., Steubing, B., Reinhard, J., Moreno-Ruiz, E., and Weidema, B. 2016. "The Ecoinvent Database Version 3 (Part I): Overview and Methodology." Int J Life Cycle Ass 21 (9): 1218-30. https://doi.org/10.1007/s11367-016-1087-8.

Yan, L., Chouw, N., and Jayaraman, K. 2014. "Flax Fibre and Its Composites - A Review." Compos Part B-Eng 56 (January): 296-317. https://doi.org/10.1016/j.compositesb.2013.08.014. 